\title{
Synthesis, Structure and Photophysical Properties of Pyrene- based [5]Helicenes: an Experimental and Theoretical study
}

\author{
Chuan-Zeng Wang, ${ }^{[a]}$ Rie Kihara, ${ }^{[a]}$ Xing Feng, ${ }^{*}{ }^{[a, b]}$ Pierre Thuéry, ${ }^{[c]}$ Carl Redshaw, ${ }^{[d]}$ and Takehiko \\ Yamato*[a]
}

\begin{abstract}
Pyrene-cored [5]helicenes were prepared by a facile, efficient Wittig reaction and an intramolecular photocyclization reaction utilising 2,7-di-tert-butylpyrene-4-carbaldehyde and naphthalene/pyrene-based phosphorus ylides. Optical properties based on UV-vis and fluorescence spectra were investigated. X-ray crystallography revealed that the pyrene-based [5]helicenes exhibited strong face-to-face $\pi-\pi$ interactions and edge-to-face $\pi-\pi$ interactions. HOMO and LUMO energies and molecular orbitals were also studied by density functional theory (DFT) calculations. This study has revealed that the torsion angle of the helical structure plays a role in determining the $\pi-\pi$ interactions and the frontier molecular orbital energy levels. Thus, pyrene-based helicenes need to be considered when one designs new highly efficient organic lightemitting diodes and organic semiconductor materials.
\end{abstract}

\section{Introduction}

Helicene and helicene-like compounds belong to the polycyclic aromatic hydrocarbons (PAHs) family and possess a non-planar structure with extended carbon-rich sp $^{2}$-hybridized scaffolds. ${ }^{1}$ Since the first example of a [n] helicene was reported way back in $1913,{ }^{2}$ the area has become a hot research topic given the relevance of these types of compounds to the generation of new functional materials for organic electronics and photovoltaics. ${ }^{3}$ However, the exploration of a facile approach for the synthesis/functionalization of helicenes in order to optimize their potential applications still remains a challenge. ${ }^{4}$ As a result of the application prospects in diverse areas of chemistry and physics due to its unique helically $\pi$ extended systems, more and more researchers have been inspired to make greater efforts to establish a practical and general methodology for the synthesis of functionalized helicenes and their hetero-analogues. ${ }^{[5]}$ Gratifyingly, significant progress has been received in this regard, which encouraged other researchers to widen the exploitation of helicene-based systems. ${ }^{5 a-c}$ The introduction of pyrene is one of the promising ways to improve the electrochemical and photophysical properties of these compounds.

Interest in pyrene [n]helicenes has emerged in the recent

[a] Department of Applied Chemistry, Faculty of Science and Engineering, Saga University, Honjo-machi 1, Saga 840-8502 Japan, E-mail: yamatot@cc.saga-u.ac.jp

[b] School of Printing and Packaging Engineering, Beijing Institute of Graphic Communication, 1 Xinghua Avenue (Band Two), Daxing, Beijing, 102600, P. R. China, E-mail: hyxhn@sina.com

[c] Service de Chimie Moléculaire, DSM, DRECAM, CNRS URA 331, CEA Saclay, 91191 Gif-sur-Yvette, France

[d] Department of Chemistry, The University of Hull, Cottingham Road Hull, Yorkshire HU6 7RX, UK

Supporting information for this article is given via a link at the end of the document.((Please delete this text if not appropriate)) years, and these efforts have contributed much to the development of the synthesis of pyrene [n]helicenes. ${ }^{6}$ Pyrene-based [7]helicenes were synthesized in the presence of $\mathrm{Ni}(\mathrm{cod})_{2}$ and (R)-QUINAP as catalyst, which exhibited excellent thermal stability and novel optical properties. $^{6 d}$ There is no doubt that photochemical synthesis was a very significant milestone in pyrene [n] helicene chemistry. Reports featured a series of pyrenecored blue-light emitting [4]helicenes, and two synthetic strategies have been established. Collins et al demonstrated that the strategy of synthesising pyrene [4] helicene hybrids using photoredox catalysis by employing a Cu-based sensitizer was feasible. ${ }^{6 b}$ Meanwhile, our group also investigated the synthetic conditions required for pyrene-based [4]helicenes, and a simple and efficient route was established via a photoinduced intramolecular cyclization. ${ }^{6 a}$ These compounds with their unique m-electron systems led to unprecedented properties and potential applications in chiral discotic liquid crystalline materials, ${ }^{7}$ building blocks for helical conjugated polymers, ${ }^{8}$ and asymmetric catalysis, ${ }^{9}$ and various other optical applications. ${ }^{10}$ It is against this background that we can predict that the design and synthesis of pyrene-based [n]helicene derivatives would be suitable for the development of light-emitting materials and other applications.

Our previous studies have shown that a simple and efficient strategy can result in pyrene [4]helicene derivatives. ${ }^{6 a}$ Therefore, in the present work, we have used the formylated compound 2,7-di-tert-butylpyrene-4carbaldehyde $2^{11}$ as the starting material for the preparation of pyrene-cored [5]helicenes. The series of synthesis of 7 has led us to a comprehensive investigation involving $X$-ray crystallography and photophysical properties as detailed below. Moreover, given the suitable energy level of the highest occupied molecular orbital (HOMO) and the $\pi-\pi$ stacking present, it is expected that pyrene-cored [5]helicenes will generate a resurgence of interest in the use of p-type semiconductors for organic thin film transistors (OTFTs).

\section{Results and Discussion}

\section{Synthesis and characterization}

Although pyrene-based chemistry is well-known, there remain considerable challenges regarding regioselectivity. In the search for new photoelectric materials, the 4,5,9,10positions of pyrene appear a very attractive alternative for preparing extended aromatic systems. However, compared with the 1-, 3-, 6-, and 8-substituted pyrenes, ${ }^{12}$ these positions are difficult to 


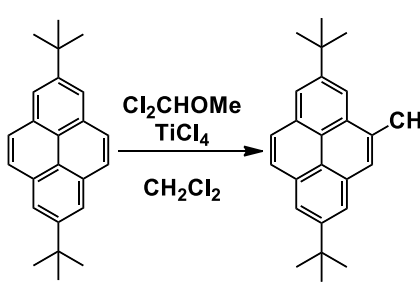

1

2

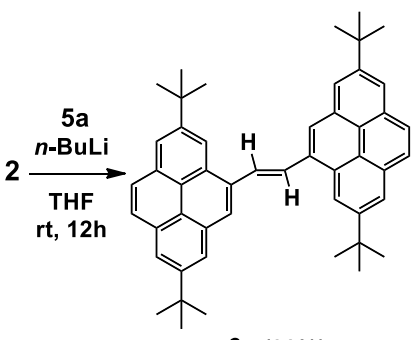

$6 a(38 \%)$

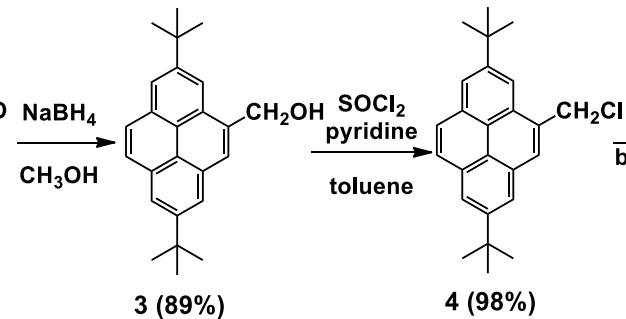

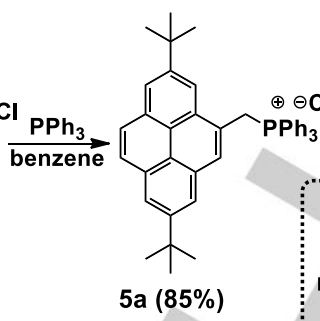
$\stackrel{\oplus \ominus \mathrm{Cl}}{\mathrm{PPh}_{3}}$

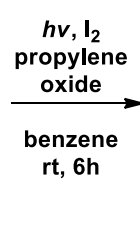

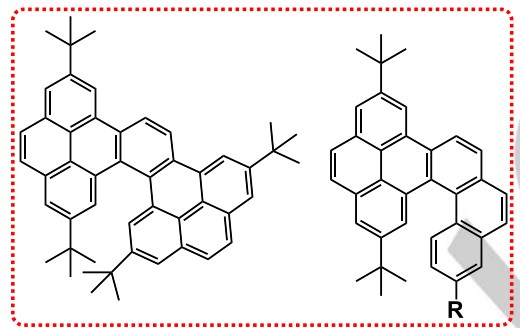

7 a $(58 \%)$
$7 b: R=H(58 \%)$
$7 c: R=O M e(65 \%)$

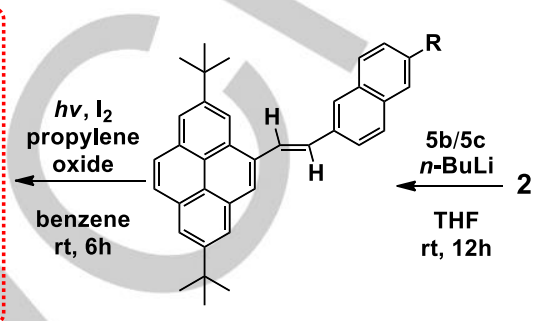

(E)-6b : R $=\mathrm{H}(73 \%)$ $6 c: R=O M e(70 \%)$ access. ${ }^{13}$ In this regard, some positive progress has been made, for example the pyrene-4,5,9,10-tetraone or it is derivatives allows for, by simple condensation reactions, a simple method for extending the conjugation and the elaboration of large PAHs. ${ }^{14}$ Collins group reported a technique for formylation at the 2-, 4- positions of pyrene, forming helicene derivatives. ${ }^{6 b}$ Indeed, several attempts to synthesize pyrenes functionalized at the 4,5,9,10-positions have been reported which utilize multistep synthetic routes and harsh reaction conditions. Herein, our work is reported against this background, and as shown in Scheme 1, the synthesis of three pyrene-cored [5]helicenes 7 starting from 2 is known. ${ }^{15}$ The synthesis was adapted from a Wittig reaction and an intramolecular photocyclization reaction as the key steps (Figure S1). Much effort has been devoted to simplify, shorten, and generalize the synthesis of $\pi-$ extended pyrene-based helicenes in this work. The efficiency of the photocyclization can be optimized dramatically, and the yield in this step reached about $60 \%$. Compared with the strategy reported by Collins, we have moved away from the dependence on Cu-based sensitizers, and reaction times have been shortened within 7 hours.

The characterization of compounds $\mathbf{6 a}$, and $7 \mathbf{a}$ are described as representative examples. The structures of the precursors $6 \mathbf{a}$ and helical-7a were determined by elemental analyses and spectroscopic data. In the case of 6a, the mass spectrum shows a molecular ion at $\mathrm{m} / \mathrm{z}=$ 652.47. The ${ }^{1} \mathrm{H}$ NMR spectrum $\left(300 \mathrm{MHz}\right.$ in $\left.\mathrm{CDCl}_{3}\right)$ exhibits two singlets at $\delta=1.58$ and $1.62 \mathrm{ppm}$ for the tert-butyl groups, and as expected, a singlet at $\delta=8.30 \mathrm{ppm}$ due to the olefinic protons (red peaks of Figure 1a). In comparison to the precursor $\mathbf{6 b}, \mathbf{6 c}$, the $E$-olefinic proton resonances of $\mathbf{6 b}$ and $\mathbf{6 c}$ are split into two doublets due to the difference of the substituents at the end of the double bond. Similarly, the protons of the pyrene core are observed as four doublets $(\delta=8.22,8.26,8.32,8.61 \mathrm{ppm})$ and two distinct singlets $(\delta=8.07,8.49 \mathrm{ppm})$. For the helical-7a, a molecular ion at $\mathrm{m} / \mathrm{z}=650.46$ was observed in the mass spectrum, and the ${ }^{1} \mathrm{H}$ NMR spectrum of this compound also provided powerful evidence for the intramolecular photocyclization from precursor 6a. There are two singlets at $\delta=1.12$ and $1.68 \mathrm{ppm}$ due to the steric hindrance of the tert-butyl groups, and the aromatic protons can clearly be seen in Figure 1b, respectively. Furthermore, all of the compounds were fully characterized by ${ }^{1} \mathrm{H} /{ }^{13} \mathrm{C}$ NMR spectra (see Figure S3-19 in the Supporting Information), singlecrystal X-ray diffraction, as well as by mass spectrometry.

(a)
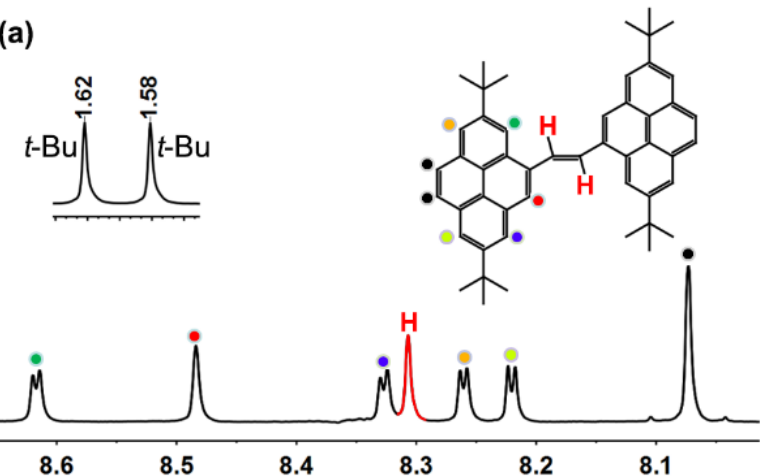

(b)
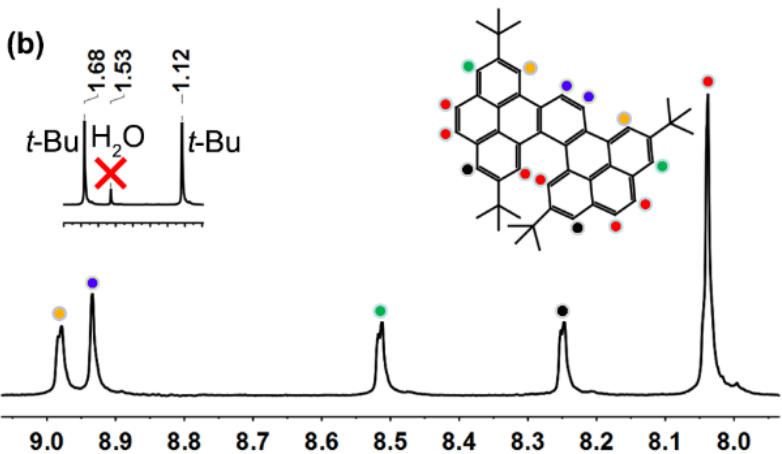

Figure 1. ${ }^{1} \mathrm{H}$ NMR spectra $\left(300 \mathrm{MHz}, \mathrm{CDCl}_{3}\right)$ of $\mathbf{6 a}$ and $7 \mathbf{a}$. 
A single crystal of $\mathbf{7 b}$ suitable for $\mathbf{X}$-ray diffraction studies was obtained by slowly evaporating a mixture of $\mathrm{CH}_{2} \mathrm{Cl}_{2}$ and hexane (1:9), which revealed the chiral helical conformation of $\mathbf{7 b}$ (Figure $2 \mathrm{a}$ ). The molecular geometry of the helical skeleton of the helicene $\mathbf{7 b}$ contains long and short $\mathrm{C}-\mathrm{C}$ bonds. As highlighted in Figure $2 \mathrm{~b}$, compared with the average bond length of benzene $(1.39 \AA)$, the longer bonds shown in red are those mostly affected by intramolecular torsion (namely C3-C10, C2-C3, C2-C25), with an average of $1.46 \AA$, while the $\mathrm{C}-\mathrm{C}$ bonds shown in blue have bond lengths close to the $\mathrm{C}-\mathrm{C}$ double bond (1.34 $\AA$ ), such as the C7-C8 bond length (1.346 ̊). The C5-C6 bond length $(1.358 \AA)$ is significantly shorter than its counterparts C3-C10 (1.458 $\AA$ ) and C2-C3 (1.450 $\mathrm{A})$, which experiences more twisting to reduce the steric hindrance within the more rigid pyrene core. The solid-state structure of [5]helicene $\mathbf{7 b}$ depicts a similar twisted helical conformation, and the torsion angles along the inner helical rim of the fjord region C11-C10-C3-C2, C10-C3-C2-C25 and C3-C2-C25-C26 are $-19.95,-32.33$ and $-13.42^{\circ}$, respectively (Figure $2 \mathrm{~b}$ ). More interestingly, the distortion angle of [5]helicenes (measured using the terminal aromatic rings) exhibit significant differences, and in the crystal of helical-7b, a distortion angle of $48.75^{\circ}$ was observed, which is in good agreement with the distortion angle of $48.91^{\circ}$ as found in the DFT energy minimized model. Meanwhile, the distortion angles of the pyrene-based [5]helicenes and the parent helicene are summarized (Figure S2), ${ }^{6 b}$ and differences of approximately $10^{\circ}$ are observed, which could be attributed to the steric hindrance of the substituents of the terminal aromatic rings.

(a)

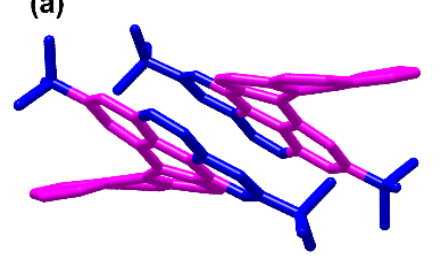

(b)

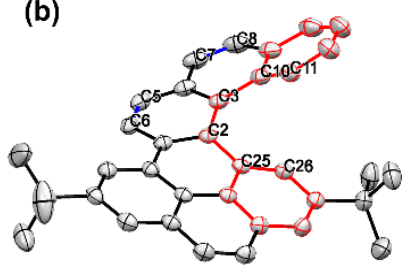

Figure 2. Crystal structure of $\mathbf{7 b}$ : (a) chiral helical conformation of helical$\mathbf{7 b}$; (b) side view of the $\pi$-backbone [5]helicene $\mathbf{7 b}$. Hydrogen atoms are partially omitted for clarity.

(a)

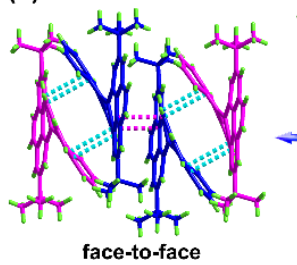

(b)
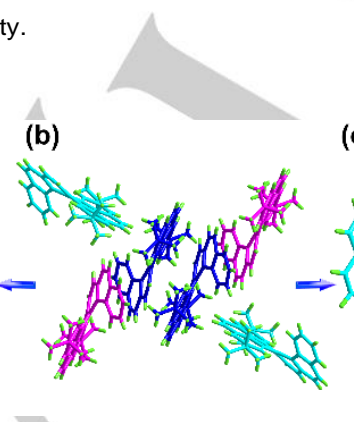

(c)

Figure 3. X-ray crystal structure representations of $\mathbf{7 b}$, illustrating (a) the detailed interactions of face-to-face $\pi-\pi$ interactions; (b) the principal intermolecular packing interactions; (c) the detailed interactions of edge-toface $\pi-\pi$ interactions.
Close inspection of the interaction of the extended $\pi$ conjugated pyrene-based helicene reveals that neighboring molecules of helical-7b interact with each other in both face-to face and edge-to-face modes. ${ }^{16}$ The unit cell of this crystal contains three pairs of enantiomers of helical-7b together with crystallized solvent molecules as shown in Figure 3b. Two pairs of enantiomers of helical-7b stack in a face-to-face arrangement with the two kinds of $\pi$-faces separated by about $3.23 \AA$ (red dashed) and within the range of 3.33 to $3.39 \AA$ (blue dashed) as shown in Figure 3a. Two neighbouring helical-7b molecules of the different handedness interact with each other in an edge-to-face arrangement by $\pi-\pi$ interactions ( $3.70 \AA$, orange dashed) as shown in Figure 3c. There are two kinds of $\pi-\pi$ interactions leading to a 3D infinite supramolecular array. ${ }^{17}$ The $\pi-\pi$ interactions can lead to special applications, such as organic light-emitting materials and as organic semiconductors both in solution and in the solid state.

\section{Photophysical properties}

The UV-vis absorption and fluorescence spectra of the pyrene-based [5]helicenes were investigated in dilute dichloromethane solution at room temperature. And the optical data is summarized in Table 1, together with the 2,7di-tert-butylpyrene $\mathbf{1}$ as a reference, which elucidate the effect of the differences of the molecular geometries on the electronic state of both the newly developed [5]helicenes 7 and the pre-cyclization products 6 (Figure 4). As expected, the molecular geometries of helical-7 and precursors 6 have a great influence on the optical properties. For the pre-cyclization products $\mathbf{6 b}$ and $\mathbf{6 c}$, two prominent absorption bands were observed in between $321-331 \mathrm{~nm}$ and 359-372 $\mathrm{nm}$. On the other hand, for the UV/vis absorption spectra of the pyrene-based [5]helicenes $\mathbf{7 b}$ and 7c, the profiles of these spectra are almost identical and the absorption bands were observed in the range of 270-400 $\mathrm{nm}$ (Figure 4a), which showed a large number of transition bands, typical of PAHs. ${ }^{18}$ However, significant differences were observed in the case of $6 \mathbf{a}$ and $7 \mathbf{a}$, respectively, which can be ascribed to the differences in the molecular geometries. Both the precursor $\mathbf{6 a}$ and the helical-7a exhibited red-shifts in comparison with $\mathbf{6 b}-\mathbf{6 c}$ and $\mathbf{7 b}-\mathbf{7 c}$. Therefore, the pronounced decrease (hypochromic absorption) of absorption bands of helical-7 in the range of $340-410 \mathrm{~nm}$ after cyclization is attributed to non-planarity, the decrease of aromaticity and the increase of distortions from the plane.

The fluorescence spectra for the pyrene-based [5]helicenes and their precursors 6 were also investigated (Figure 4b). The fluorescence spectra follow a similar trend with a shoulder as was observed for the UV-vis absorption data. Compared with the emission band of 2,7-di-tertbutylpyrene 1 at $378 \mathrm{~nm}$, the emission bands of 6 and 7 are obviously red-shifted to 479 (6a), 446 (6b, 6c), 464 (7a) and $427 \mathrm{~nm}(\mathbf{7 b}, 7 \mathrm{c})$, respectively. Both absorption bands were observed in the visible blue region. Remarkably high quantum yields are observed for compound 6, implying an 
effective energy transfer from the excited states to the emitters. This is caused by the greater $\pi$ conjugation along the naphthylethenyl or pyrene-based ethenyl unit at the 4position in the pyrene ring (Table 1), with the formation of the helical structure, which weakened the effect due to the twist angle to a certain extent. So the fluorescence quantum yields of 7 are lower compared with the precursors 6 because of the lower electron delocalization around the aromatic core after cyclization.

Table 1. Photophysical properties of compounds 6 and 7.[a]

\begin{tabular}{|c|c|c|c|c|}
\hline Compounds & $\begin{array}{c}\text { Absorption }^{[\mathrm{b}]} \\
\lambda_{\mathrm{abs}}[\mathrm{nm}]\end{array}$ & $\begin{array}{l}\lambda_{\max }[\mathrm{nm}]\left(\lambda_{\mathrm{ex}}\right)^{[\mathrm{d}]} \\
\lambda^{[\mathrm{c}]}\end{array}$ & $\begin{array}{l}\text { Stokes-shift } \\
{[\mathrm{nm}]}\end{array}$ & $\Phi_{f}[\mathrm{e}]$ \\
\hline $6 a$ & 346 & $479(317)$ & 133 & 0.95 \\
\hline $6 b$ & 359 & $446(321)$ & 87 & 0.90 \\
\hline $6 c$ & 361 & 446 (327) & 85 & 0.73 \\
\hline $7 a$ & 343 & 464 (316) & 121 & 0.18 \\
\hline $7 b$ & 333 & 427 (272) & 94 & 0.09 \\
\hline $7 c$ & 334 & $427(274)$ & 93 & 0.06 \\
\hline 1 & 339 & 378 (252) & 39 & 0.12 \\
\hline
\end{tabular}

[a] All measurements were performed under degassed conditions. [b] $\times 10^{-5} \mathrm{M}$ in $\mathrm{CH}_{2} \mathrm{Cl}_{2}, \lambda_{\text {abs }}$ is the absorption band appearing at the longest wavelength. [c] $\sim \times 10^{-6} \mathrm{M}$ in $\mathrm{CH}_{2} \mathrm{Cl}_{2}, \lambda_{\mathrm{ex}}$ is the fluorescence band appearing at the shortest wavelength. [d] Wavelength of excitation. [e] Absolute quantum yield in $\mathrm{CH}_{2} \mathrm{Cl}_{2}$ at $\sim \times 10^{-6} \mathrm{M}$.
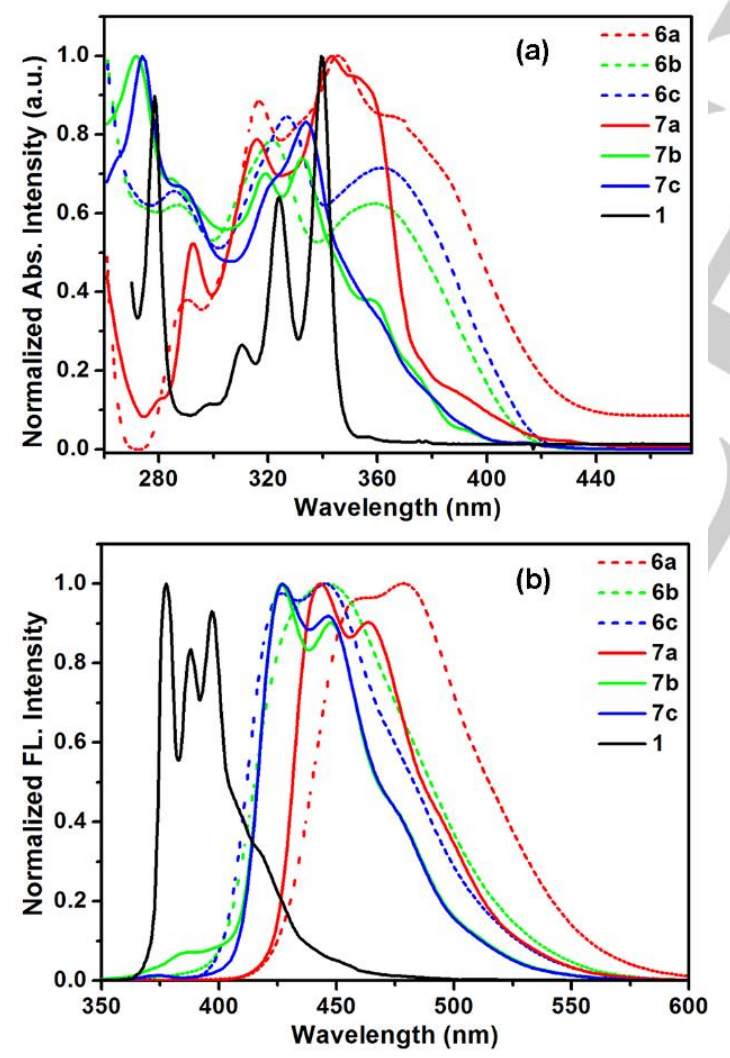

Figure 4. (a) Normalized UV-vis absorption and (b) emission spectra of compounds 6 and 7 recorded in dichloromethane at ca. $10^{-5}-10^{-6} \mathrm{M}$ at $25^{\circ} \mathrm{C}$.

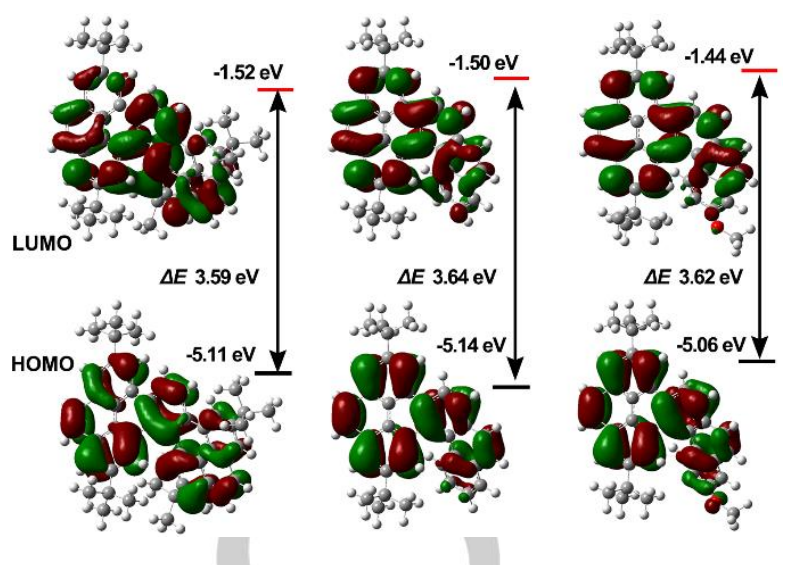

Figure 5. Computed molecular orbital plots (B3LYP/6-31G*) of 7, up for LUMOs and down for HOMOs.

\section{Quantum chemistry calculations}

In order to understand the frontier molecular orbitals and the structure-property relationships of helical-7, density functional theory calculations were performed with the B3LYP function and the $6-31 \mathrm{G}^{*}$ basis sets. The geometries and electronic structures associated with 7 are depicted in Figure 5 . In the case of 7 , the LUMOs and HOMOs were completely localized on the parent pyrene-based [5]helicenes and revealed delocalization spread over the entire molecule, and the detailed HOMO and LUMO energy levels were calculate. Meanwhile, the we also obtained the band gap energy from optical measurements ( $\left.E_{\text {gap-opt }}\right)$ of helical7 from the absorption edge of the UV-Vis spectra (3.61 eV for $\mathbf{7 a}, 3.72 \mathrm{eV}$ for $\mathbf{7 b}$, and $3.71 \mathrm{eV}$ for $\mathbf{7 c}$ ), respectively (Table S1). Not surprisingly, the decreasing theoretical HOMO-LUMO gaps ( $E_{\text {gap-theo }}$ ) (3.59 eV for 7a, $3.64 \mathrm{eV}$ for $7 \mathbf{b}$, and $3.62 \mathrm{eV}$ for $\mathbf{7 c}$ ) are consistent with the slight red-shift (333 nm for $\mathbf{7 b}$, $334 \mathrm{~nm}$ for 7c, $343 \mathrm{~nm}$ for 7a) and estimated band gap from optical measurements. The red-shifted absorption of helical molecules may be attributed to the severe distortion of the helical system, which leads to redistribution of electrons in the HOMO and LUMO. Finally, the DFT calculations of this system provided a convincing evidence to demonstrate the experimental results, such as X-ray structure, UV absorption spectra, and so on.

\section{Conclusions}

In summary, we have achieved a convenient synthesis of the pyrene-based [5] helicenes 7. The highly distorted $\pi$-conjugated system was unambiguously confirmed by $X$ ray crystallography, NMR spectroscopies and mass spectrometry. The established synthetic strategy here will assist us to rapidly access a variety of fascinating helical $\pi$ extended aromatic molecules. It is expected that this work will generate an upsurge of interest in helicene molecules for applications as high-performance organic photonics materials, such as highly efficient OLED devices, and new organic semiconductors. 


\section{Experimental}

All melting points (Yanagimoto MP-S1) are uncorrected. ${ }^{1} \mathrm{H}$ NMR spectra (300 MHz) were recorded on a Nippon Denshi JEOL FT-300 NMR spectrometer with $\mathrm{SiMe}_{4}$ as an internal reference: $J$-values are given in $\mathrm{Hz}$. IR spectra were measured for samples as $\mathrm{KBr}$ pellets in a Nippon Denshi JIR-AQ2OM spectrophotometer. UV-vis spectra were recorded on a Perkin Elmer Lambda 19 UV/VIS/NIR spectrometer. Mass spectra were obtained on a Nippon Denshi JMS-01SA-2 spectrometer at $75 \mathrm{eV}$ using a direct-inlet system. Elemental analyses were performed by Yanaco MT-5.

\section{Materials}

Unless otherwise stated, all other reagents used were purchased from commercial sources and were used without further purification. The preparations of 2,7-di-tert-butylpyrene (1) and 2,7-di-tert-butylpyrene-4carbaldehyde (2) were described previously. ${ }^{11}$

\section{Synthetic Procedures}

\section{Synthesis of (2,7-di-tert-butylpyrene-4-yl)methanol (3)}

To a solution of compound $2(1.00 \mathrm{~g}, 2.92 \mathrm{mmol})$ and methanol (50 $\mathrm{mL}$ ) was slowly added sodium borohydride (442 $\mathrm{mg}, 11.7 \mathrm{mmol}$ ) at room temperature. The mixture was stirred $3 \mathrm{~h}$ at room temperature and refluxed for $12 \mathrm{~h}$ at $70{ }^{\circ} \mathrm{C}$ under argon. The mixture was quenched by adding a large amount of ice-water, extracted with dichloromethane $(2 \times$ $50 \mathrm{~mL}$ ), washing with water, followed by brine solution and was finally dried over anhydrous $\mathrm{MgSO}_{4}$ and concentrated under reduced pressure. The residue obtained was finally washed with hexane and recrystallized in dichloromethane to obtained $\mathbf{3}$ as a white crystalline solid. (892 $\mathrm{mg}$, $89 \%)$; M.p. $137-138{ }^{\circ} \mathrm{C}$; ${ }^{1} \mathrm{H}$ NMR $\left(300 \mathrm{MHz}, \mathrm{CDCl}_{3}\right): \delta_{\mathrm{H}}=1.57$ (s, 9H, tBu), 1.59 (s, 9H, tBu), $1.86(\mathrm{t}, J=6.0 \mathrm{~Hz}, 1 \mathrm{H},-\mathrm{OH}), 5.37(\mathrm{~d}, J=6.0 \mathrm{~Hz}$, $\left.2 \mathrm{H},-\mathrm{CH}_{2}-\right), 8.02(\mathrm{~s}, 2 \mathrm{H}$, pyrene- $H), 8.09(\mathrm{~s}, 1 \mathrm{H}$, pyrene- $H), 8.18-8.21(\mathrm{~m}$, $3 \mathrm{H}$, pyrene- $H$ ), $8.42\left(\mathrm{~d}, J=1.7 \mathrm{~Hz}, 1 \mathrm{H}\right.$, pyrene- $H$ ) ppm; ${ }^{13} \mathrm{C}$ NMR $(100$ $\left.\mathrm{MHz}, \mathrm{CDCl}_{3}\right): \delta_{\mathrm{c}}=31.9,32.0,35.2,35.4,64.4,118.2,122.3,122.4$, $122.7,123.3,126.2,127.3,127.7,128.9,130.2,130.7,131.2,135.4$, 148.6, 148.8 ppm; FAB-MS: $\mathrm{m} / \mathrm{z}$ calcd for $\mathrm{C}_{25} \mathrm{H}_{28} \mathrm{O} 344.21$ [M+]; found 344.25 [M+]; elemental analysis calcd (\%) for $\mathrm{C}_{25} \mathrm{H}_{28} \mathrm{O}$ (344.49): C 87.16, H 8.19; found C 87.00, H 8.17.

\section{Synthesis of 2,7-di-tert-butyl-4-(chloromethyl)pyrene (4)}

To a solution of compound $3(850 \mathrm{mg}, 2.47 \mathrm{mmol})$ and toluene $(75$ $\mathrm{mL}$ ) was added a mixture of $\mathrm{SOCl}_{2}(2.15 \mathrm{~mL}, 29.60 \mathrm{mmol})$ and pyridine $(0.2 \mathrm{~mL})$ at room temperature. The mixture was stirred for 3 hours at room temperature and refluxed for $3 \mathrm{~h}$ at $110{ }^{\circ} \mathrm{C}$. Then the reaction mixture was stirred at room temperature for $2 \mathrm{~h}$. The mixture was quenched by adding a large amount of ice-water, extracted with ethyl acetate $(2 \times 50 \mathrm{~mL})$, washed with $10 \% \mathrm{NaHCO}_{3}$, water, brine solution and finally was dried over anhydrous $\mathrm{MgSO}_{4}$ and concentrated. The residue obtained was washed with $\mathrm{MeOH}$ to afford a white solid compound which was recrystallized in hexane to obtain 4 as colorless prisms. (894 mg, 98\%); M.p. $140-142{ }^{\circ} \mathrm{C} ;{ }^{1} \mathrm{H} \mathrm{NMR}\left(300 \mathrm{MHz}, \mathrm{CDCl}_{3}\right): \delta_{\mathrm{H}}$ $=1.57(\mathrm{~s}, 9 \mathrm{H}, t-\mathrm{Bu}), 1.61(\mathrm{~s}, 9 \mathrm{H}, t-\mathrm{Bu}), 5.28\left(\mathrm{~s}, 2 \mathrm{H},-\mathrm{CH}_{2}-\right), 8.02(\mathrm{~d}, J=$ $1.3 \mathrm{~Hz}, 2 \mathrm{H}$, pyrene- $H$ ), 8.11 (s, $1 \mathrm{H}$, pyrene- $H$ ), 8.18-8.20 (m, 2H, pyrene$H$ ), $8.22(\mathrm{~d}, J=1.6 \mathrm{~Hz}, 1 \mathrm{H}$, pyrene- $H), 8.47(\mathrm{~d}, J=1.8 \mathrm{~Hz}, 1 \mathrm{H}$, pyrene- $H)$ ppm; ${ }^{13} \mathrm{C} \mathrm{NMR}\left(100 \mathrm{MHz}, \mathrm{CDCl}_{3}\right): \delta_{\mathrm{c}}=31.9,32.0,35.2,35.4,45.7,118.8$ $122.5,122.7,122.9,123.0,123.4,127.3,127.7,128.4,129.2,129.8$, 130.7, 131.2, 132.2, 148.6, 148.9 ppm; FAB-MS: m/z calcd for $\mathrm{C}_{25} \mathrm{H}_{27} \mathrm{Cl}$
$362.18\left[\mathrm{M}^{+}\right]$; found $362.18\left[\mathrm{M}^{+}\right]$; elemental analysis calcd (\%) for $\mathrm{C}_{25} \mathrm{H}_{27} \mathrm{Cl}$ (362.93): C 82.73, H 7.50; found C 82.46, H 7.47.

\section{Synthesis of Wittig reagent $5 a$}

A solution of compound $4(1.5 \mathrm{~g}, 4.13 \mathrm{mmol})$ was added dropwise to benzene $(20 \mathrm{~mL})$ at room temperature and stirred for $15 \mathrm{~min}$. Then $\mathrm{PPh}_{3}$ $(2.17 \mathrm{~g}, 8.27 \mathrm{mmol})$ was slowly added. The reaction mixture was heated to reflux and continuously stirred for 3 days. After cooling to room temperature, it was filtered, and then washed with benzene and hexane to give pure compound $5 \mathrm{a}(2.2 \mathrm{~g}, 85 \%)$; M.p. $304-306{ }^{\circ} \mathrm{C} ;{ }^{1} \mathrm{H}$ NMR $(300$ $\left.\mathrm{MHz}, \mathrm{CDCl}_{3}\right): \delta_{\mathrm{H}}=1.28(\mathrm{~s}, 9 \mathrm{H}, t-\mathrm{Bu}), 1.52(\mathrm{~s}, 9 \mathrm{H}, t-\mathrm{Bu}), 6.30$ (d, $J=14.3$ $\left.\mathrm{Hz}, 2 \mathrm{H},-\mathrm{CH}_{2}-\right), 7.36$ (s, 2H, Ar-H), 7.48 (td, $J=7.7 \mathrm{~Hz}, 6 \mathrm{H}, \mathrm{Ar}-H$ ), 7.66 $(\mathrm{m}, 4 \mathrm{H}, \mathrm{Ar}-\mathrm{H}), 7.72-7.81(\mathrm{~m}, 6 \mathrm{H}, \mathrm{Ar}-\mathrm{H}), 7.96(\mathrm{~d}, J=2.3 \mathrm{~Hz}, 1 \mathrm{H}$, pyreneH) ppm, $8.00(\mathrm{~d}, J=4.7 \mathrm{~Hz}, 1 \mathrm{H}$, pyrene- $H$ ), $8.14(\mathrm{~d}, J=4.4 \mathrm{~Hz}, 1 \mathrm{H}$, pyrene- $H$ ), $8.18(\mathrm{~s}, 1 \mathrm{H}$, pyrene- $H$ ). Due to the poor solubility, it was not further identified by ${ }^{13} \mathrm{C}$ NMR spectroscopy. FAB-MS: $\mathrm{m} / \mathrm{z}$ calcd for $\mathrm{C}_{43} \mathrm{H}_{42} \mathrm{CIP} 624.27\left[\mathrm{M}^{+}\right]$; found $624.28\left[\mathrm{M}^{+}\right]$; elemental analysis calcd (\%) for $\mathrm{C}_{25} \mathrm{H}_{27} \mathrm{Cl}$ (624.28): C 82.60, H 6.77; found C 82.63, H 6.72.

\section{Synthesis of precursor $6 \mathbf{a}$}

To a solution of Wittig reagent $5 \mathbf{a}(685 \mathrm{mg}, 1.10 \mathrm{mmol})$ in dry THF (15 $\mathrm{mL}$ ) was slowly added $n$-butyllithium in hexane $(0.69 \mathrm{~mL}, 1.10 \mathrm{mmol})$ at $0{ }^{\circ} \mathrm{C}$ under argon. The mixture was stirred for $10 \mathrm{~min}$ and a solution of 2 $(250 \mathrm{mg}, 0.73 \mathrm{mmol})$ in dry THF $(15 \mathrm{~mL})$ was injected under the same conditions. After this addition, the mixture was warmed to room temperature, and was stirred for $12 \mathrm{~h}$ under argon. The mixture was quenched by adding a large amount of ice-water and was then extracted with dichloromethane $(3 \times 50 \mathrm{~mL})$. A pale yellow solid obtained during extraction was filtered and the filtrate obtained was further washed with water followed by brine and was dried over anhydrous $\mathrm{MgSO}_{4}$ and concentrated. The residue was adsorbed on silica gel and column chromatographed over silica gel (Wako C-300, 200 g) with hexane/chloroform (7:3) as eluent to give a mixture of $(E, Z)$-isomers (NMR analysis) as a light-yellow solid (437 mg). Recrystallization from hexane and dichloromethane afforded $(E)-6 \mathbf{a}(181 \mathrm{mg}, 38 \%)$ as a lightyellow solid; M.p. ${ }^{359-360}{ }^{\circ} \mathrm{C} .{ }^{1} \mathrm{H} \mathrm{NMR}\left(300 \mathrm{MHz}, \mathrm{CDCl}_{3}\right)$ : $\delta_{\mathrm{H}}=1.58(\mathrm{~s}$, $18 \mathrm{H}, t-\mathrm{Bu}), 1.62(\mathrm{~s}, 18 \mathrm{H}, t-\mathrm{Bu}), 8.07(\mathrm{~s}, 4 \mathrm{H}$, pyrene- $H$ ), $8.22(\mathrm{~d}, J=1.8 \mathrm{~Hz}$, $2 \mathrm{H}$, pyrene- $H$ ), $8.26(\mathrm{~d}, J=1.7 \mathrm{~Hz}, 2 \mathrm{H}$, pyrene- $H$ ), $8.30(\mathrm{~s}, 2 \mathrm{H},-\mathrm{CH}=\mathrm{CH}-$ ), $8.32(\mathrm{~d}, J=1.7 \mathrm{~Hz}, 2 \mathrm{H}$, pyrene- $H$ ), $8.48(\mathrm{~s}, 1 \mathrm{H}$, pyrene- $H$ ), 8.61 (d, $J=$ $1.7 \mathrm{~Hz}, 2 \mathrm{H}$, pyrene- $H$ ) ppm; ${ }^{13} \mathrm{C} \mathrm{NMR}\left(100 \mathrm{MHz}, \mathrm{CDCl}_{3}\right): \delta_{\mathrm{c}}=32.0,32.1$, $35.3,35.5,118.8,122.2,122.4,122.8,123.1,125.6,127.4,127.8,129.8$, 129.9, 130.7, 130.8, 131.2, 135.2, 148.6, 148.9 ppm; FAB-MS: m/z calcd for $\mathrm{C}_{50} \mathrm{H}_{52} 652.41\left[\mathrm{M}^{+}\right]$; found $652.47\left[\mathrm{M}^{+}\right]$; elemental analysis calcd (\%) for $\mathrm{C}_{50} \mathrm{H}_{52}$ (652.95): C 92.66, H 7.34; found C 92.51, H 7.30.

\section{Synthesis of 2,7-di-tert-butyl-4-(2-naphtylethenyl)pyrene (E-6b)}

The Wittig reagent was prepared from triphenylphosphane and 2 (bromomethyl)naphthalene in dry benzene. To a solution of this Wittig reagent $5 \mathbf{b}(529 \mathrm{mg}, 1.10 \mathrm{mmol})$ in dry THF $(15 \mathrm{~mL})$ was slowly added $n$ butyllithium in hexane $(0.69 \mathrm{~mL}, 1.10 \mathrm{mmol})$ at $0{ }^{\circ} \mathrm{C}$ under argon. The mixture was stirred for $10 \mathrm{~min}$ and the solution of $2(250 \mathrm{mg}, 0.73 \mathrm{mmol})$ in dry THF (15 mL) was injected under the same conditions. After this addition, the mixture was warmed to room temperature, stirring for $12 \mathrm{~h}$ under argon. The mixture was quenched by adding a large amount of ice-water and was extracted with dichloromethane $(2 \times 100 \mathrm{~mL})$. The combined extracts were washed with water followed by drying with $\mathrm{MgSO}_{4}$ and concentrated. The residue was adsorbed on silica gel and 
column chromatographed over silica gel (Wako C-300, $200 \mathrm{~g}$ ) with hexane/chloroform (7:3) as eluent to give (E)-6b (NMR analysis) as a white solid. Recrystallization from hexane/dichloromethane $(9: 1, \mathrm{v} / \mathrm{v})$ afforded the anti-compound (E)-6b (249 mg, 73\%) as a white solid; M.p. 190-193 ${ }^{\circ} \mathrm{C} .{ }^{1} \mathrm{H}$ NMR $\left(300 \mathrm{MHz}, \mathrm{CDCl}_{3}\right): \delta_{\mathrm{H}}=1.60(\mathrm{~s}, 9 \mathrm{H}, t-\mathrm{Bu}), 1.61$ (s, $9 \mathrm{H}, t$-Bu), 7.46-7.55 (m, 2H, Ar- $H$ ), 7.56 (d, $J=15.9 \mathrm{~Hz}, 1 \mathrm{H},-\mathrm{CH}=\mathrm{CH}_{\mathrm{a}-}$ ), 7.86-7.97 (m, 4H, Ar-H), 8.01 (s, 1H, Ar- H), 8.04 (s, 2H, pyrene- $H$ ), 8.17 (d, $J=15.9 \mathrm{~Hz}, 1 \mathrm{H},-\mathrm{CH}_{b}=\mathrm{CH}-$ ), $8.18(\mathrm{~d}, J=1.8 \mathrm{~Hz}, 1 \mathrm{H}$, pyrene- $H$ ), 8.23 (d, $J=1.8 \mathrm{~Hz}, 1 \mathrm{H}$, pyrene- $H$ ), 8.25 (d, $J=1.8 \mathrm{~Hz}, 1 \mathrm{H}$, pyrene- $H$ ), 8.34 (s, $1 \mathrm{H}$, pyrene- $H$ ), $8.55\left(\mathrm{~d}, J=1.8 \mathrm{~Hz}, 1 \mathrm{H}\right.$, pyrene- $H$ ) ppm; ${ }^{13} \mathrm{C}$ NMR $(100$ $\left.\mathrm{MHz}, \mathrm{CDCl}_{3}\right): \delta_{\mathrm{C}}=32.0,32.1,35.2,35.5,118.5,122.1,122.3,122.4$, $122.6,123.1,123.9,125.0,126.0,126.4,126.9,126.9,127.3,127.7$, $127.8,128.1,128.5,129.7,130.6,130.7,131.2,132.0,133.2,133.8$, 134.7, 135.3, 148.5, 148.9 ppm; FAB-MS: $\mathrm{m} / \mathrm{z}$ calcd for $\mathrm{C}_{36} \mathrm{H}_{34} 466.27$ $\left[\mathrm{M}^{+}\right]$; found $466.30\left[\mathrm{M}^{+}\right]$; elemental analysis calcd (\%) for $\mathrm{C}_{36} \mathrm{H}_{34}(466.66)$ : C 92.66, H 7.34; found C 92.51, H 7.30.

\section{Synthesis of 2,7-di-tert-butyl-4-((2-methoxynaphthalen-6- yl)ethenyl)pyrene ( $E-6 c)$}

The Wittig reagent was prepared from triphenylphosphane and 2 (bromomethyl)-6-methoxynaphthalene in dry benzene. To a solution of this Wittig reagent $5 \mathrm{c}(565 \mathrm{mg}, 1.10 \mathrm{mmol})$ in dry THF $(15 \mathrm{~mL})$ was slowly added $n$-butyl lithium in hexane $(0.69 \mathrm{~mL}, 1.10 \mathrm{mmol})$ at $0{ }^{\circ} \mathrm{C}$ under argon. The mixture was stirred for 10 mins and the solution of 2 (250 mg, $0.73 \mathrm{mmol})$ in dry THF (15 mL) was injected under the same conditions. After this addition, the mixture was warmed to room temperature stirring for $12 \mathrm{~h}$ under argon. The mixture was quenched by adding a large amount of ice-water, and was extracted with dichloromethane $(2 \times 100 \mathrm{~mL})$. The combined extracts were washed with water followed by drying with $\mathrm{MgSO}_{4}$ and concentrated. The residue was adsorbed on silica gel and column chromatographed over silica gel (Wako C-300, $200 \mathrm{~g}$ ) with hexane/chloroform (1:1) as eluent to give (E)6c ( ${ }^{1} \mathrm{H}$ NMR analysis) as a white solid. Recrystallization from hexane/dichloromethane $(5: 1, \mathrm{v} / \mathrm{v})$ afforded the anti-compound $(E)-6 \mathrm{c}$ (254 mg, 70\%) as a white solid.; M.p. $166-167{ }^{\circ} \mathrm{C} .{ }^{1} \mathrm{H}$ NMR $(300 \mathrm{MHz}$, $\left.\mathrm{CDCl}_{3}\right): \delta_{\mathrm{H}}=1.59(\mathrm{~s}, 9 \mathrm{H}, t-\mathrm{Bu}), 1.61(\mathrm{~s}, 9 \mathrm{H}, t-\mathrm{Bu}), 3.96$ (s, 3H, Ar-OMe), 7.17-7.21 (m, 2H, Ar- $\mathrm{H}), 7.53\left(\mathrm{~d}, J=15.7 \mathrm{~Hz}, 1 \mathrm{H},-\mathrm{CH}=\mathrm{CH}_{\mathrm{a}^{-}}\right), 7.80(\mathrm{~d}, J$ $=4.2 \mathrm{~Hz}, 1 \mathrm{H}, \mathrm{Ar}-\mathrm{H}), 7.83(\mathrm{~d}, J=2.3 \mathrm{~Hz}, 1 \mathrm{H}, \mathrm{Ar}-\mathrm{H}), 7.90-7.94(\mathrm{~m}, 2 \mathrm{H}, \mathrm{Ar}-$ $H$ ), $8.03\left(\mathrm{~s}, 2 \mathrm{H}\right.$, pyrene- $H$ ), $8.12\left(\mathrm{~d}, J=15.9 \mathrm{~Hz}, 1 \mathrm{H},-\mathrm{CH}_{\mathrm{b}}=\mathrm{CH}-\right), 8.17(\mathrm{~d}$, $J=1.8 \mathrm{~Hz}, 1 \mathrm{H}$, pyrene- $H$ ), $8.23(\mathrm{~d}, J=1.7 \mathrm{~Hz}, 1 \mathrm{H}$, pyrene- $H$ ), $8.24(\mathrm{~d}, J$ $=1.7 \mathrm{~Hz}, 1 \mathrm{H}$, pyrene- $H), 8.33(\mathrm{~s}, 1 \mathrm{H}$, pyrene- $H), 8.55(1 \mathrm{H}, \mathrm{d}, J=1.7 \mathrm{~Hz}$, pyrene- $H$ ) ppm; ${ }^{13} \mathrm{C}$ NMR $\left(100 \mathrm{MHz}, \mathrm{CDCl}_{3}\right): \delta_{\mathrm{C}}=32.0,32.1,35.2,35.5$, $55.4,106.1,118.6,119.1,122.0,122.3,122.4,122.6,123.1,124.5$, $124.9,125.9,126.7,127.3,127.7,129.2,129.7,129.8,130.7,130.8$, 131.2, 132.1, 133.3, 134.4, 134.8, 148.4, 148.9, 158.0 ppm; FAB-MS: $\mathrm{m} / \mathrm{z}$ calcd for $\mathrm{C}_{37} \mathrm{H}_{36} \mathrm{O} 496.28\left[\mathrm{M}^{+}\right]$; found $496.32\left[\mathrm{M}^{+}\right]$; elemental analysis calcd (\%) for $\mathrm{C}_{37} \mathrm{H}_{36} \mathrm{O}$ (496.68): C 89.47, H 7.31; found C 89.32, H 7.31.

\section{General procedure for photocyclization}

The photo reactor was a cylindrical glass vessel with an immersion well and two tapered joints. A vertical one was attached to a condenser to which an argon source was fitted. The other joint is angled for withdrawal and addition of samples. The vessel was flat bottomed to allow a magnetic stirring bar to rotate. The immersion well was a double walled pyrex tube cooled by water and containing a high pressure quartz $\mathrm{Hg}$ vapour lamp. Argon gas was bubbled through benzene for 20-30 min. and used to dissolve the sample and iodine. The dissolved solutions of sample, iodine and propylene oxide were added to the reaction vessel through the angled joint and the lamp was turned on. The reaction was carried out under an argon atmosphere. Photo reactions were monitored by ${ }^{1} \mathrm{H}$ NMR spectroscopy and iodine colour change. After complete irradiation, work included washing with $15 \% \mathrm{Na}_{2} \mathrm{~S}_{2} \mathrm{O}_{3} \cdot \mathrm{H}_{2} \mathrm{O}$ and saturated brine, drying with anhydrous $\mathrm{MgSO}_{4}$, filtering and concentrated to dryness on a rotary evaporator. The residue obtained was washed either through a short column of silica gel or different solvent systems were used to obtain the pure compounds.

\section{Synthesis of helical-7a}

(E)-6a (100 mg, $0.15 \mathrm{mmol})$ in $250 \mathrm{~mL}$ of benzene was irradiated in the presence of $\mathrm{I}_{2}(46.7 \mathrm{mg}, 0.18 \mathrm{mmol})$ and propylene oxide $(3.00 \mathrm{~mL}$, $42.9 \mathrm{mmol}$ ) for $8 \mathrm{~h}$. Work-up involved being adsorbed on silica gel using dichloromethane and column chromatographed using hexane/chloroform (7:3) as eluent. The compound obtained was further recrystallized in dichloromethane/methanol system to compound $7 \mathrm{a}(78.2 \mathrm{mg}, 78 \%)$ as a pale yellow solid.; M.p. $388-389{ }^{\circ} \mathrm{C} .{ }^{1} \mathrm{H}$ NMR $\left(300 \mathrm{MHz}, \mathrm{CDCl}_{3}\right): \delta_{\mathrm{H}}=$ $1.12(\mathrm{~s}, 18 \mathrm{H}, t-\mathrm{Bu}), 1.68(\mathrm{~s}, 18 \mathrm{H}, t-\mathrm{Bu}), 8.03(\mathrm{~s}, 6 \mathrm{H}, \operatorname{Ar}-H), 8.25$ (d, $J=$ $1.5 \mathrm{~Hz}, 2 \mathrm{H}, \mathrm{Ar}-H$ ), 8.51 (d, J=1.7 Hz, 2H, Ar-H), $8.93(\mathrm{~s}, 2 \mathrm{H}, \mathrm{Ar}-H), 8.98$ (d, $J=1.4 \mathrm{~Hz}, 2 \mathrm{H}, \mathrm{Ar}-H$ ) ppm; ${ }^{13} \mathrm{C} \mathrm{NMR}\left(100 \mathrm{MHz}, \mathrm{CDCl}_{3}\right)$ : $\delta \mathrm{c}=31.4$, 32.1, 34.8, 35.5, 117.9, 122.2, 122.6, 122.8, 126.0, 126.9, 127.8, 128.6, 129.3, 129.5, 130.9, 131.2, 131.2, 146.7, 149.0 ppm; FAB-MS: m/z calcd for $\mathrm{C}_{50} \mathrm{H}_{50} 650.39\left[\mathrm{M}^{+}\right]$; found $650.46\left[\mathrm{M}^{+}\right]$; elemental analysis calcd (\%) for $\mathrm{C}_{50} \mathrm{H}_{50}$ (650.93): C 93.06, H 6.94; found : C 92.97, H 6.71.

\section{Synthesis of helical-7b}

2,7-Di-tert-butyl-4-(2-naphtylethenyl)pyrene $(E)$-6b $\quad(100 \mathrm{mg}, \quad 0.21$ $\mathrm{mmol})$ in $250 \mathrm{~mL}$ of benzene was irradiated in the presence of $\mathrm{I}_{2}(63.9$ $\mathrm{mg}, 0.25 \mathrm{mmol}$ ) and propylene oxide ( $3.00 \mathrm{~mL}, 42.9 \mathrm{mmol}$ ) for $6 \mathrm{~h}$. Workup involved adsorbing on silica gel using dichloromethane and column chromatographed using hexane/chloroform (8:2) as eluent. The compound obtained was further recrystallized from a dichloromethane/methanol system to afford compound $7 \mathrm{~b}(56.6 \mathrm{mg}$, $58 \%)$ as a pale yellow solid.; M.p. $200-202{ }^{\circ} \mathrm{C} .{ }^{1} \mathrm{H}$ NMR $(300 \mathrm{MHz}$, $\left.\mathrm{CDCl}_{3}\right): \delta_{\mathrm{H}}=1.26(\mathrm{~s}, 9 \mathrm{H}, t-\mathrm{Bu}), 1.65(\mathrm{~s}, 9 \mathrm{H}, t-\mathrm{Bu}), 7.12-7.18(\mathrm{~m}, 1 \mathrm{H}, \mathrm{Ar}-$ H), 7.46 (t, $J=7.0 \mathrm{~Hz}, 1 \mathrm{H}, \mathrm{Ar}-\mathrm{H}) 7.91$ (s, 2H, Ar-H), 7.93 (d, $J=10.8 \mathrm{~Hz}$, $1 \mathrm{H}, \operatorname{Ar}-H$ ), 8.02 (d, $J=6.4 \mathrm{~Hz}, 1 \mathrm{H}, \operatorname{Ar}-H), 8.03$ (s, 2H, Ar-H), 8.09 (d, $J=$ $1.7 \mathrm{~Hz}, 1 \mathrm{H}, \operatorname{Ar}-H), 8.23(\mathrm{~d}, J=1.7 \mathrm{~Hz}, 1 \mathrm{H}, \operatorname{Ar}-H), 8.35(\mathrm{~d}, J=8.4 \mathrm{~Hz}, 1 \mathrm{H}$, Ar- $H$ ), $8.77(\mathrm{~d}, J=1.4 \mathrm{~Hz}, 1 \mathrm{H}, \mathrm{Ar}-H), 8.83(\mathrm{~d}, J=8.6 \mathrm{~Hz}, 1 \mathrm{H}, \mathrm{Ar}-H), 8.92$ ppm (d, $J=1.5 \mathrm{~Hz}, 1 \mathrm{H}, \mathrm{Ar}-H)$; ${ }^{13} \mathrm{C} \mathrm{NMR}\left(100 \mathrm{MHz}, \mathrm{CDCl}_{3}\right)$ : $\delta_{\mathrm{C}}=31.5$, 32.0, 35.0, 35.5, 122.1, 122.3, 122.4, 122.6, 122.7, 124.5, 125.3, 126.0, $126.2,127.0,127.5,127.5,127.6,127.8,127.9,128.1,128.7,128.8$, $129.7,130.7,131.1,131.1,131.3,132.5,132.8,146.8,148.8$ ppm; FABMS: $\mathrm{m} / \mathrm{z}$ calcd for $\mathrm{C}_{36} \mathrm{H}_{32} 464.25\left[\mathrm{M}^{+}\right]$; found $464.64\left[\mathrm{M}^{+}\right]$; elemental analysis calcd (\%) for $\mathrm{C}_{36} \mathrm{H}_{32}$ (464.64): C 93.06, H 6.94; found : C 92.97 , H 6.71 .

\section{Synthesis of helical-7c}

2,7-Di-tert-butyl-4-((2-methoxynaphthalen-6-yl)ethenyl)- pyrene (E)-6c (100 mg, $0.20 \mathrm{mmol}$ ) in $250 \mathrm{~mL}$ of benzene was irradiated in the presence of $\mathrm{I}_{2}(60.8 \mathrm{mg}, 0.24 \mathrm{mmol})$ and propylene oxide $(3.00 \mathrm{~mL}, 44.4$ mmol) for $6 \mathrm{~h}$. Work-up involved adsorbing on silica gel using dichloromethane and was column chromatographed using hexane/chloroform (7:3) as eluent. The compound obtained was further recrystallized from a dichloromethane/methanol system to afford compound 7c $(64.4 \mathrm{mg}, 65 \%)$ as a pale yellow solid.; M.p. $98-99^{\circ} \mathrm{C} .{ }^{1} \mathrm{H}$ NMR (300 MHz, CDCl $)$ : $\delta_{\mathrm{H}}=1.29(\mathrm{~s}, 9 \mathrm{H}, t-\mathrm{Bu}), 1.66(\mathrm{~s}, 9 \mathrm{H}, t-\mathrm{Bu}), 3.96$ (s, 3H, OMe), 6.81 (dd, $J=2.7,9.2 \mathrm{~Hz}, 1 \mathrm{H}, \mathrm{Ar}-H), 7.28(\mathrm{~d}, J=2.8 \mathrm{~Hz}, 1 \mathrm{H}$, 
Ar-H) $7.83(\mathrm{~d}, J=8.6 \mathrm{~Hz}, 1 \mathrm{H}$, Ar- $H$ ), $7.89(\mathrm{~d}, J=8.6 \mathrm{~Hz}, 1 \mathrm{H}, \mathrm{Ar}-H), 8.00$ (d, $J=8.4 \mathrm{~Hz}, 1 \mathrm{H}, \mathrm{Ar}-\mathrm{H}$ ), 8.03 (s, 2H, Ar-H), $8.08(\mathrm{~d}, J=1.8 \mathrm{~Hz}, 1 \mathrm{H}, \mathrm{Ar}-$ H), $8.22(\mathrm{~d}, J=1.7 \mathrm{~Hz}, 1 \mathrm{H}, \mathrm{Ar}-\mathrm{H}), 8.26(\mathrm{~d}, J=5.5 \mathrm{~Hz}, 1 \mathrm{H}, \operatorname{Ar}-\mathrm{H}), 8.76(\mathrm{~d}$, $J=8.8 \mathrm{~Hz}, 1 \mathrm{H}, \operatorname{Ar}-H), 8.79(\mathrm{~d}, J=1.7 \mathrm{~Hz}, 1 \mathrm{H}, \operatorname{Ar}-H), 8.91(\mathrm{~d}, J=1.7 \mathrm{~Hz}$, $1 \mathrm{H}, \mathrm{Ar}-H) \mathrm{ppm} ;{ }^{13} \mathrm{C} \mathrm{NMR}\left(100 \mathrm{MHz}, \mathrm{CDCl}_{3}\right): \delta_{\mathrm{C}}=31.6,32.0,35.0,35.5$, $55.4,107.3,115.5,118.2,121.2,122.3,122.4,122.6,122.6,124.9$, $126.0,126.8,127.0,127.4,127.6,127.6,128.4,128.8,129.0,130.8$, $131.1,131.1,131.2,131.4,134.4,146.8,148.8,157.7$ ppm; FAB-MS: $\mathrm{m} / \mathrm{z}$ calcd for $\mathrm{C}_{37} \mathrm{H}_{34} 494.26$ [M+]; found 494.30 [M+]; elemental analysis calcd (\%) for $\mathrm{C}_{37} \mathrm{H}_{34}$ (494.67): C 88.84, H 6.93; found : C 88.83, H 7.12.

\section{X-ray Crystallography}

A suitable single crystal (ca. $0.2 \times 0.2 \times 0.1 \mathrm{~mm}^{3}$ ) was selected and mounted on a Bruker APEX 2 CCD diffractometer equipped with graphite-monochromated Mo-Ka radiation for $\mathbf{7 b} .{ }^{19}$ Data were corrected for Lorentz and polarisation effects and for absorption. ${ }^{19}$ Analytical expressions for neutral-atom scattering factors were employed, and anomalous dispersion corrections were incorporated. Details of the crystal parameters, data collection conditions, and refinement parameters for the this compound is summarized in Table S2. Crystallographic data for the structures in this paper have been deposited with the Cambridge Crystallographic Data Centre as supplementary publication numbers CCDC 1496976. Copies of the data can be obtained, free of charge, on application to CCDC, 12 Union Road, Cambridge CB2 1EZ, UK [fax: 144-1223-336033 or e-mail: deposit@ccdc.cam.ac.uk].

Supporting Information: Details of single-crystal X-ray crystallographic data. ${ }^{1} \mathrm{H},{ }^{13} \mathrm{C}$ NMR of precursor-6 and helical7, associated with this article are supplied.

\section{Acknowledgements}

This work was performed under the Cooperative Research Program of "Network Joint Research Center for Materials and Devices (Institute for Materials Chemistry and Engineering, Kyushu University)". We would like to thank the OTEC at Saga University and the International Cooperation Projects of Guizhou Province (No. 20137002), The Royal Society of Chemistry for financial support and the EPSRC for an overseas travel grant to C.R.

Keywords: Pyrene-cored [5] helicenes $\cdot$ Photocyclization $\bullet \pi-\pi$ interactions $\cdot$ DFT calculations $\cdot$ Optical properties

[1] a) S. Grimme, J. Harren, A. Sobanski, F. Voegtle, Eur. J. Org. Chem. 1998, 1491-1509; b) I. G. Stara, I. Stary, Sci. Synth. 2010, 45, 885-953; c) I. Sato, R. Yamashima, K. Kadowaki, J. Yamamoto, T. Shibata, K. Soai, Angew.Chem. Int. Ed. 2001, 40, 1096-1098; d) J. Misek, F. Teply, I. G. Stara, M. Tichy, D. Saman, I. Cisarova, P. Vojtisek, I. Stary, Angew.Chem. Int. Ed. 2008, 47, 31883191; e) E. Anger, M. Srebro, N. Vanthuyne, L. Toupet, S. Rigaut, C. Roussel, J. Autschbach, J. Crassous, R. Reau, J. Am. Chem. Soc. 2012, 134, 15628-15631; f) M. Gingras, Chem. Soc. Rev. 2013, 42, 968-1006.

[2] R. Weitzenböck, H. Lieb, Monatsh. Chem. 1913, 33, 549565.

[3] a) J. E. Field, G. Muller, J. P. Riehl, D. Venkataraman, J. Am. Chem. Soc. 2003, 125, 11808-11809; b) C. Kim, T. J. Marks, A. Facchetti, M. Schiavo, A. Bossi, S. Maiorana,
E. Licandro, F. Todescato, S. Toffanin, M. Muccini, C. Graiff, A. Tiripicchio, Org. Electron. 2009, 10, 15111520; c) L. Q. Shi, Z. Liu, G. F. Dong, L. Duan, Y. Qiu, J. Jia, W. Guo, D. Zhao, D. L. Cui, X. T. Tao, Chem. Eur. J. 2012, 18, 8092-8099; d) W. M. Hua, Z. Liu, L. Duan, G. F. Dong, Y. Qiu, B. J. Zhang, D. L. Cui, X. T. Tao, N. Cheng, Y. J. Liu, $R S C A d v$. 2015, 5, 75-84; e) S. Jhulki, A. K. Mishra, J. N. Moorthy, T. J. Chow, Chem. Eur. J. 2016, 22, 9375-9386.

[4] a) M. Gingras, Chem. Soc. Rev. 2013, 42, 1051-1095; b) T. Katayama, S. Nakatsuka, H. Hirai, N. Yasuda, J. Kumar, T. Kawai, T. Hatakeyama, J. Am. Chem. Soc. 2016, 138, 5210-5213; c) Y. Yamamoto, H. Sakai, J. Yuasa, Y. Araki, T. Wada, T. Sakanoue, T. Takenobu, T. Kawai, T. Hasobe, Chem. Eur. J. 2016, 22, 4263-4273.

[5] a) M. Gingras, G. Félix, R. Peresutti, Chem. Soc. Rev. 2013, 42, 1007-1050; b) Y. Shen, C. F. Chen, Chem. Rev. 2012, 112, 1463-1535; c) A. Urbano, Angew. Chem. Int. Ed. 2003, 42, 3986-3989; d) S. K. Collins, M. P. Vachon, Org. Biomol. Chem. 2006, 4, 2518-2524; e) C. L. Eversloh, Z. H. Liu, B. Müller, M. Stangl, C. Li, K. Müllen, Org. Lett. 2011, 13, 5528-5531.

[6] a) J. Y. Hu, X. Feng, A. Paudel, H. Tomiyasu, U. Rayhan, P. Thuery, M. R. J. Elsegood, C. Redshaw, T. Yamato, Eur. J. Org. Chem. 2013, 5829-5837; b) A. C. Bédard, A. Vlassova, A. C. Hernandez-Perez, A. Bessette, G. S. Hanan, M. A. Heuft, S. K. Collins, Chem. Eur. J. 2013, 19, 16295-16302; c) H. Bock, D. Subervie, P. Mathey, A. Pradhan, P. Sarkar, P. Dechambenoit, E. A. Hillard, F. Durola, Org. Lett. 2014, 16, 1546-1549; d) M. Buchta, J. Rybáček, A. Jančařík, A. A. Kudale, M. Buděšínský, J. V. Chocholoušová, J. Vacek, L. Bednárová, I. Císařová, G. J. Bodwell, I. Starý, I. G. Stará, Chem. Eur. J. 2015, 21, 8910-8917.

[7] a) L. Vyklicky, S. H. Eichhorn, T. J. Katz, Chem. Mater. 2003, 15, 3594-3601; b) J. Kelber, M. F. Achard, F. Durola, H. Bock, Angew.Chem. Int.Ed. 2012, 51, 52005203.

[8] a) T. Mori, K. Akagi, Macromolecules 2013, 46, 66996711 ; b) Y. Y. Xu, G. Yang, H. Y. Xia, G. Zou, Q. J. Zhang, J. G. Gao, Nat. Commun. 2014, 5, 5050.

[9] a) A. Desmarchelier, X. Caumes, M. Raynal, A. VidalFerran, L. Van, W. N. M. Piet, L. Bouteiller, J. Am. Chem. Soc. 2016, 138, 4908-4916; b) J. J. Li, M. Du, Z. Q. Zhao, H. W. Liu, Macromolecules 2016, 49, 445-454.

[10] a) T. Iwasaki, H. Nishide, Curr.Org. Chem. 2005, 9, 1665-1684; b) M. Li, L. H. Feng, H. Y. Lu, S. Wang, C. F. Chen, Adv. Funct. Mater. 2014, 24, 4405-4412.

[11] a) J. Y. Hu, A. Paudel, T. Yamato, J. Chem. Res. 2009, 109-113; b) J. Y. Hu, A. Paudel, N. Seto, X. Feng, M Era, T. Matsumoto, J. Tanaka, M. R. J. Elsegood, C. Redshaw, T. Yamato, Org. Biomol. Chem. 2013, 11, 2186-2197.

[12] a) M. J. S. Dewar, R. D. Dennington, J. Am. Chem. Soc. 1989, 111, 3804-3808; b) J. Y. Hu, X. Feng, N. Seto, J. H. Do, X. Zeng, Z. Tao, T. Yamato, J. Mol. Struct. 2013 , 1047, 194-265.

[13] a) M. Tashiro, T. Yamato, J. Am. Chem. Soc. 1982, 104, 3707-3710; b) M. Minabe, S. Takeshige, Y. Soeda, T. Kimura, M. Tsubata, Bull. Chem. Soc. Jpn. 1994, 67, 172179; c) T. Yamato, J. Y. Hu, J. Chem. Res. 2006, 762 765 .

[14] a) X. Gong, W. L. Ma, J. C. Ostrowski, G. C. Bazan, D. Moses, A. J. Heeger, Adv. Mater. 2004, 16, 615-619; b) Y, Fogel, M. Kastler, Z. H. Wang, D. Andrienko, G. J. Bodwell, G. K. Müllen, J. Am. Chem. Soc. 2007, 129, 11743-11749.

[15] X. Feng, J. Y. Hu, C. Redshaw, T. Yamato, Chem. Eur. J. 2016, 22, 11898-11916. 
[16] H. Xia, D. Q. Liu, K. S. Song, Q. Miao, Chem. Sci. 2011, 2, 2402-2406.

[17] T. Siegrist, C. Kloc, J. H. Schön, B. Ballogg, R. C. Haddon, S. Berg, G. A. Thomas, Angew. Chem. Int. Ed. 2001, 40, 1732-1736.
[18] D. Wasserfallen, M. Kastler, W. Pisula, W. A. Hofer, Y. Borgel, Z. Wang, K. Mullen, J. Am. Chem. Soc. 2006, $128,1334-1339$.

[19] APEX 2 \& SAINT (2012), software for CCD diffractometers. Bruker AXS Inc., Madison, USA. 
6
Entry for the Table of Contents (Please choose one layout)

Layout 1:

\section{FULL PAPER}

This work presents a facile, efficient, general strategy for the synthesis of pyrene-based [5]helicenes. Optical properties of those helical compounds based on UV-vis and fluorescence spectra were investigated. It is expected that this work will generate an upsurge of interest in helicene molecules for applications as highperformance organic photonics materials, such as highly efficient OLED devices, and new organic

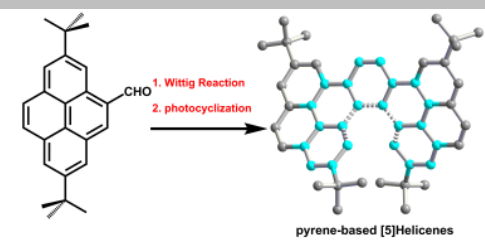

Chuan-Zeng Wang, , Rie Kihara, ${ }^{a}$ Xing Feng, ${ }^{\star a, b}$ Pierre Thuéry, ${ }^{c}$ Carl Redshaw, ${ }^{d}$ and Takehiko Yamato*a

\section{Page 1 - Page 8}

Synthesis, Structure and

Photophysical Properties of Pyrene-

based [5]Helicenes: an Experimental and Theoretical study 
Click here to access/download Supporting Information slct.201601327 Supporting Information.pdf 
(a)
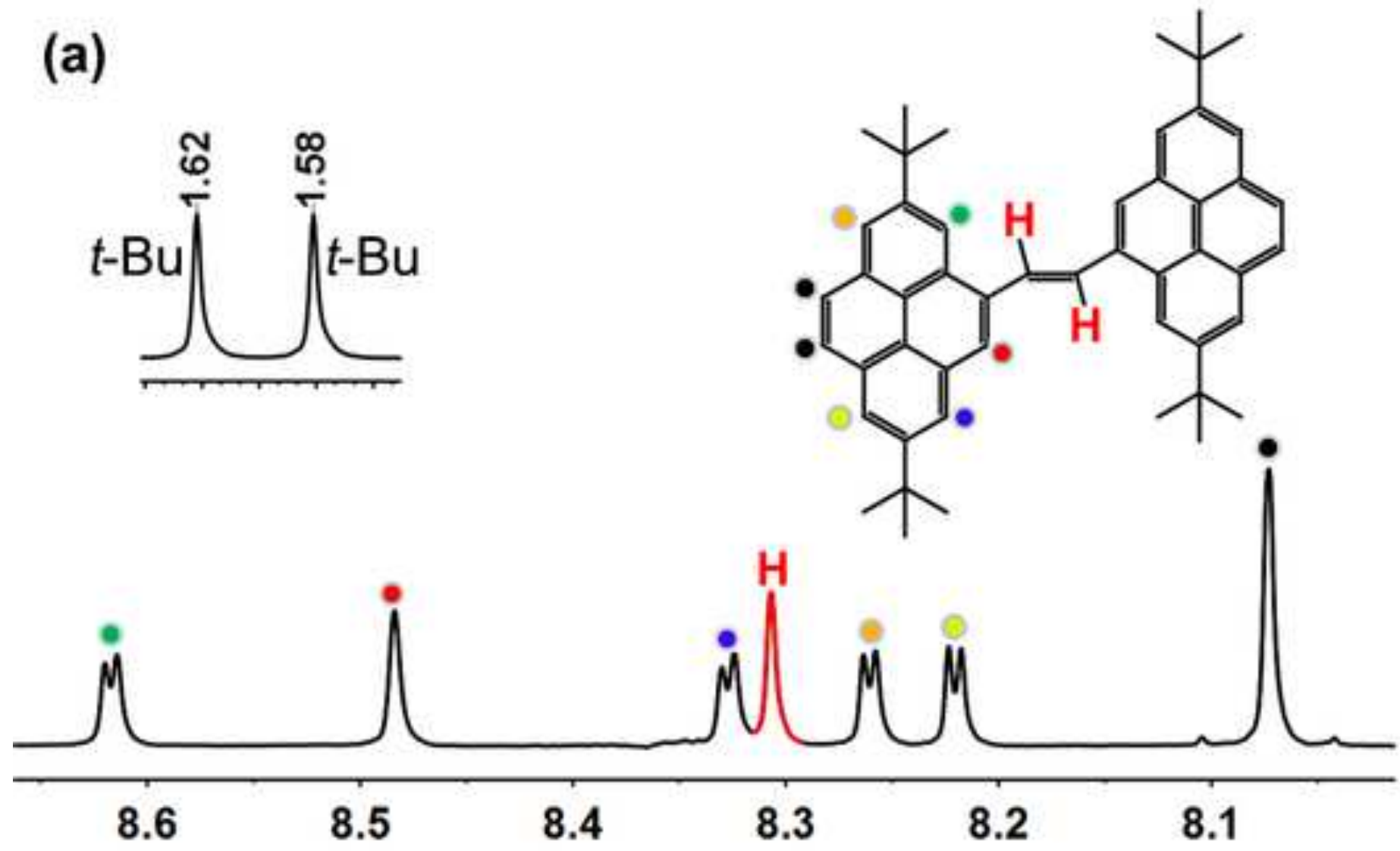

(b)

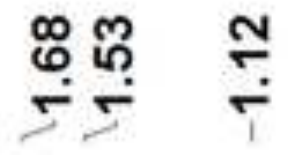
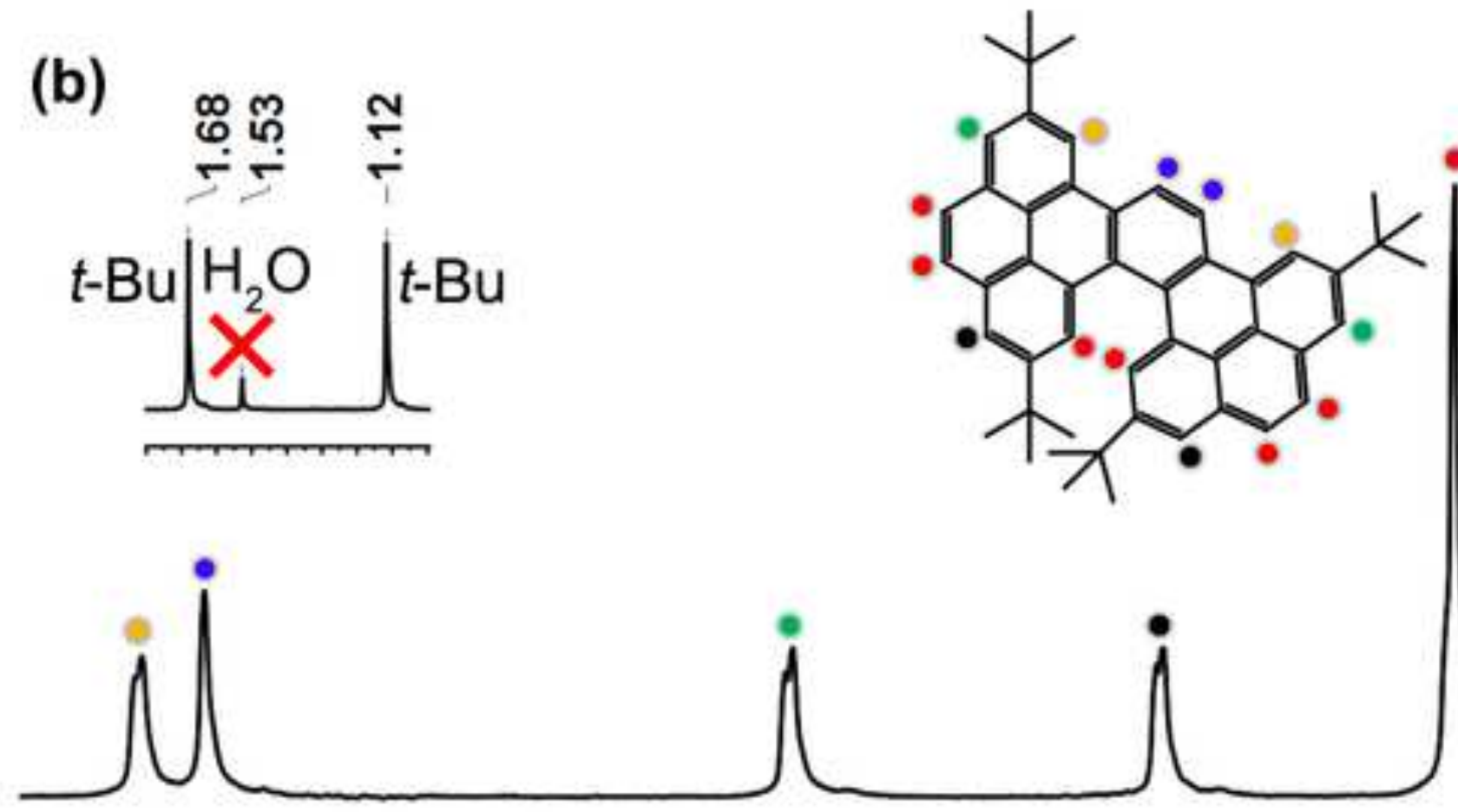

$\begin{array}{lllllllllll}9.0 & 8.9 & 8.8 & 8.7 & 8.6 & 8.5 & 8.4 & 8.3 & 8.2 & 8.1 & 8.0\end{array}$ 
(a)

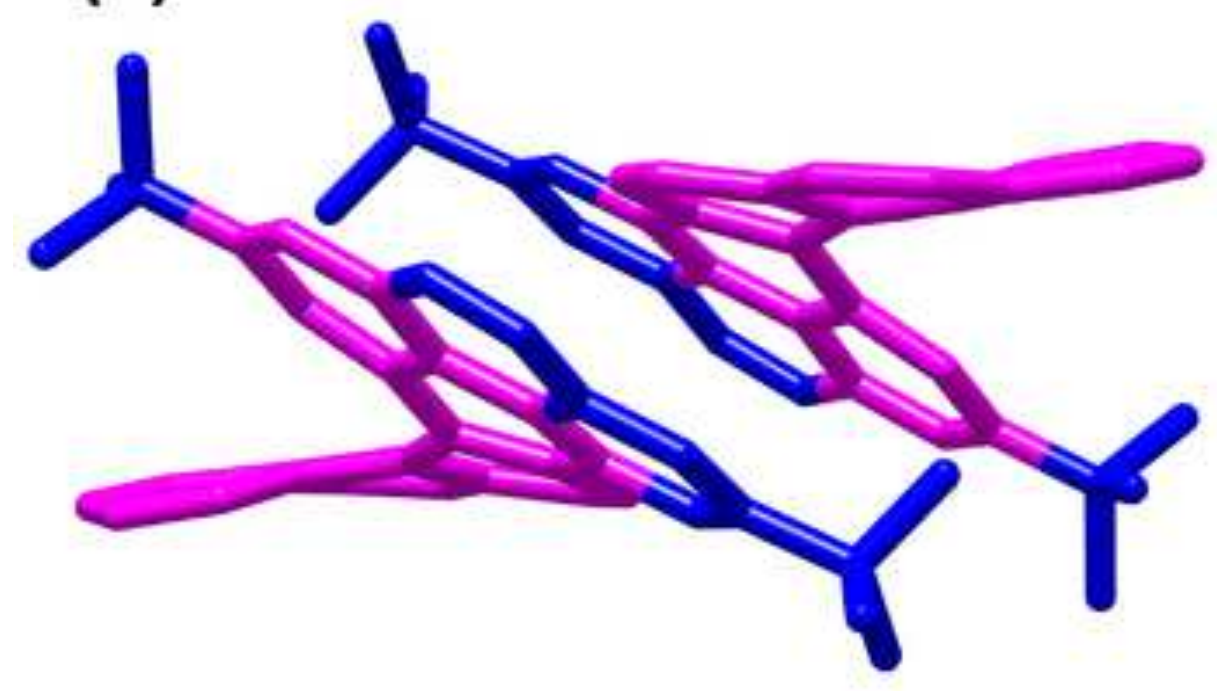

(b)

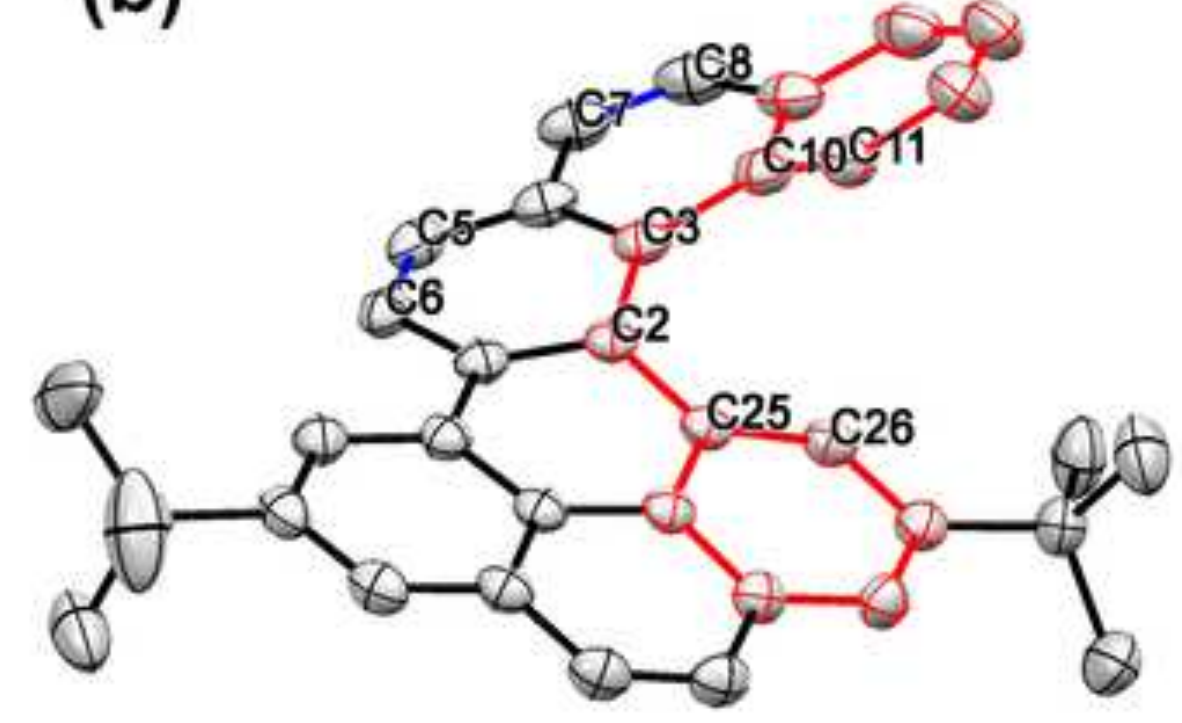


(a)

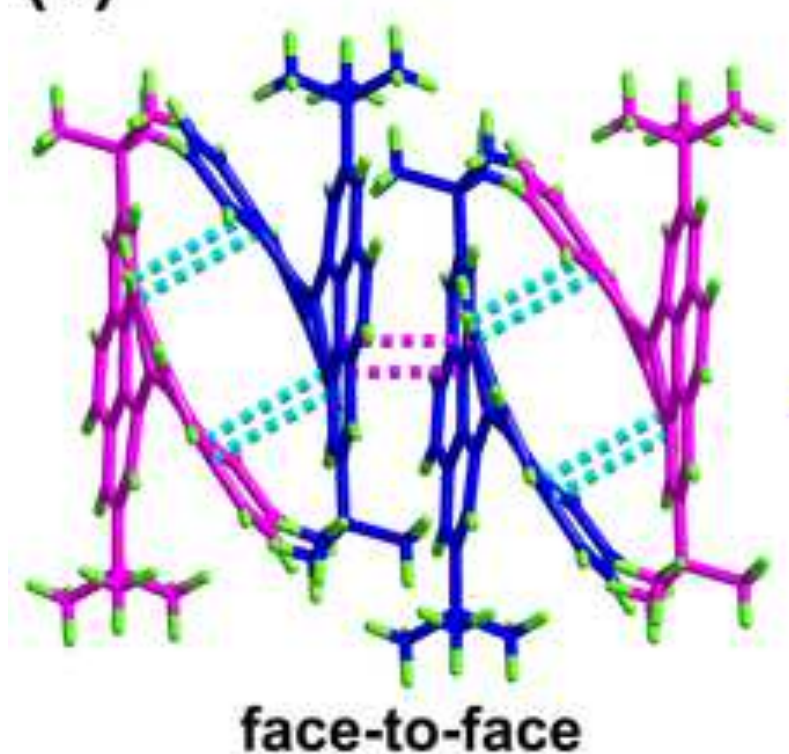

(b)

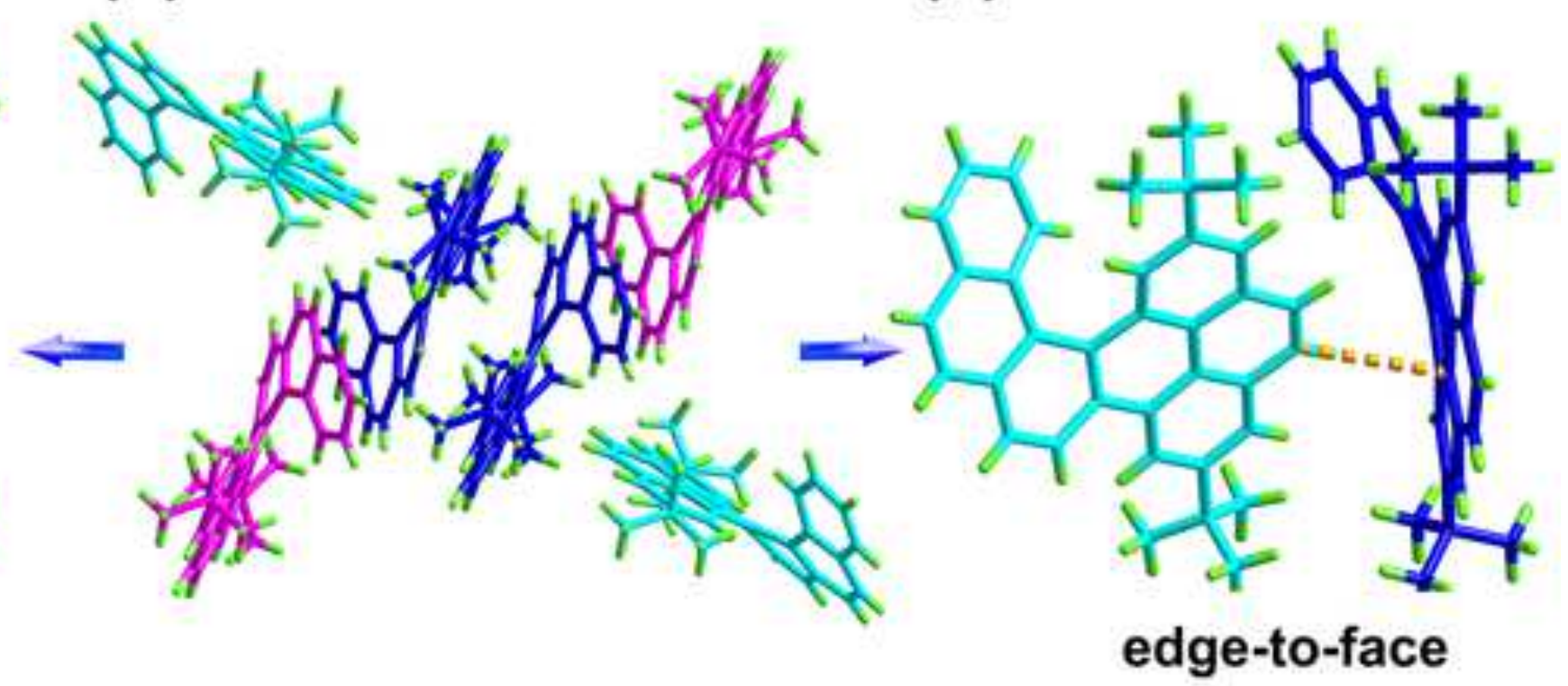


Click here to download Graphical Material slct.201601327 Figure \pm
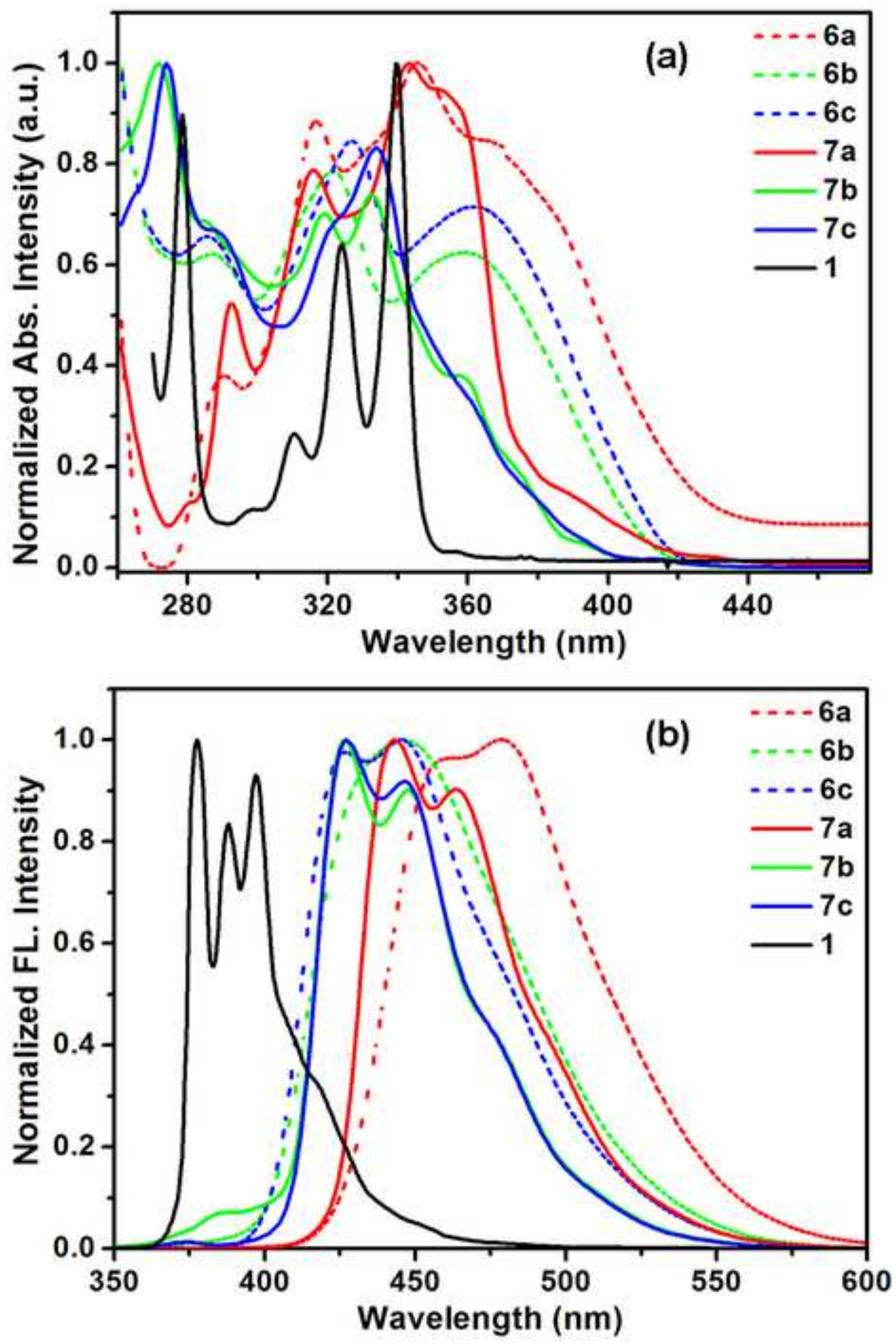

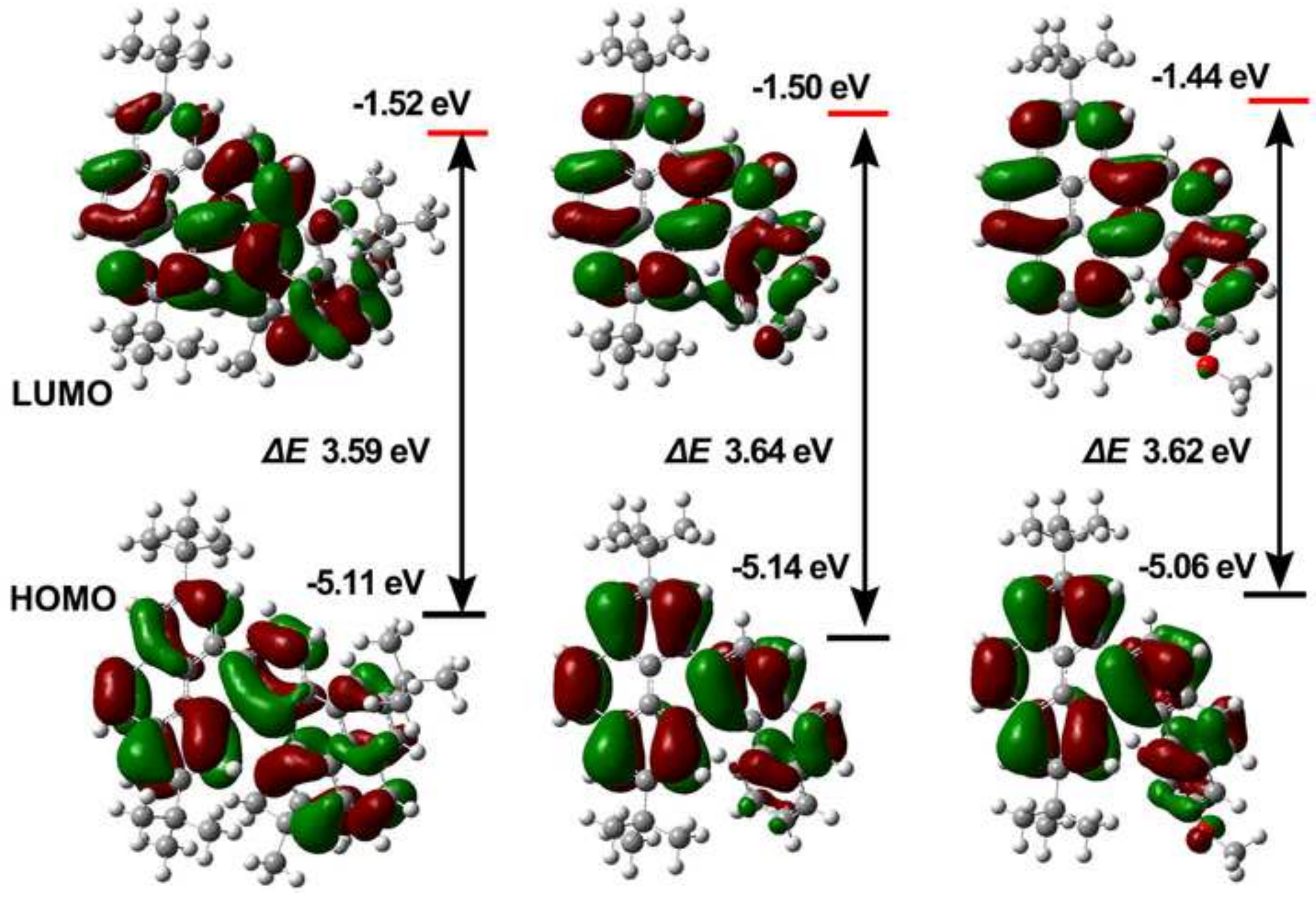

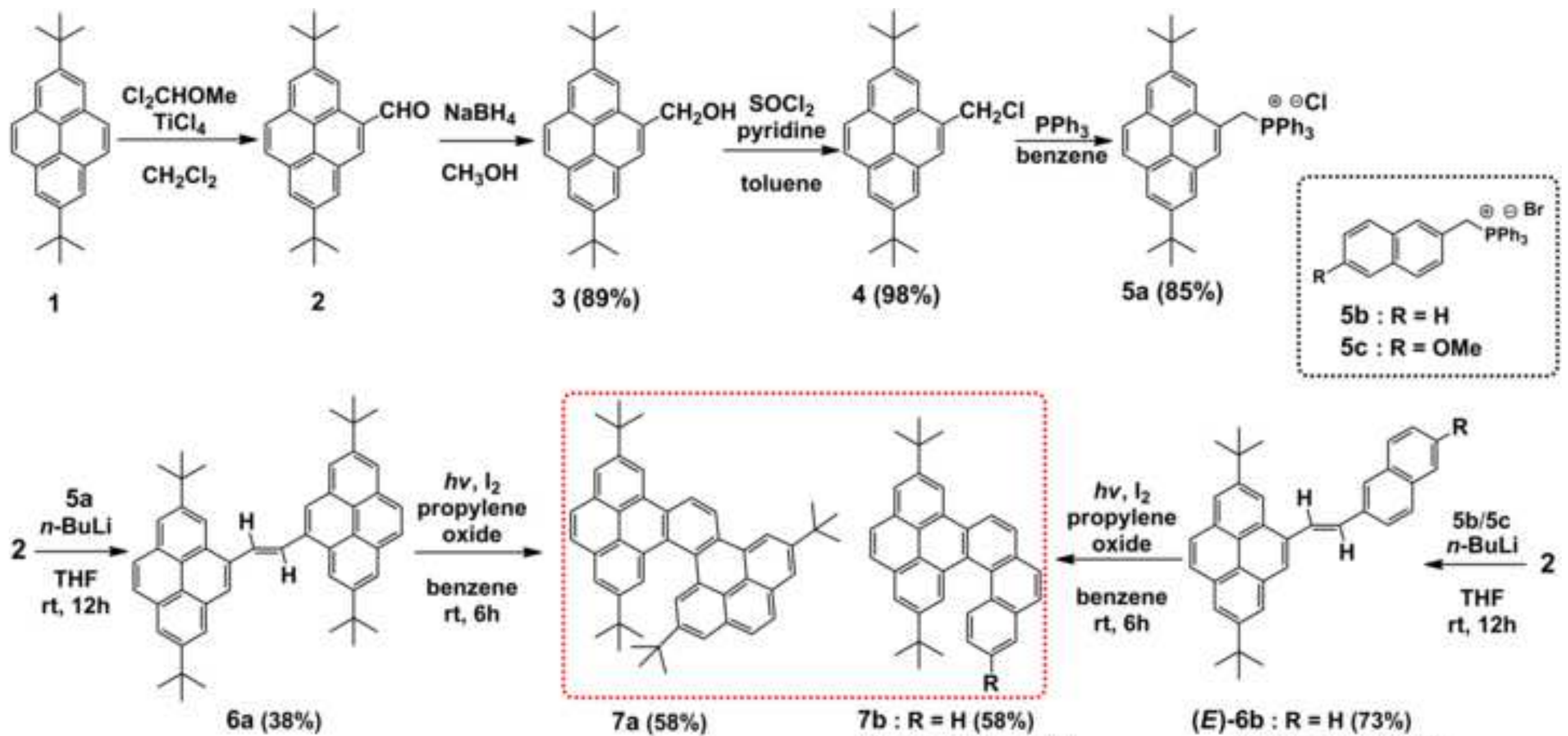

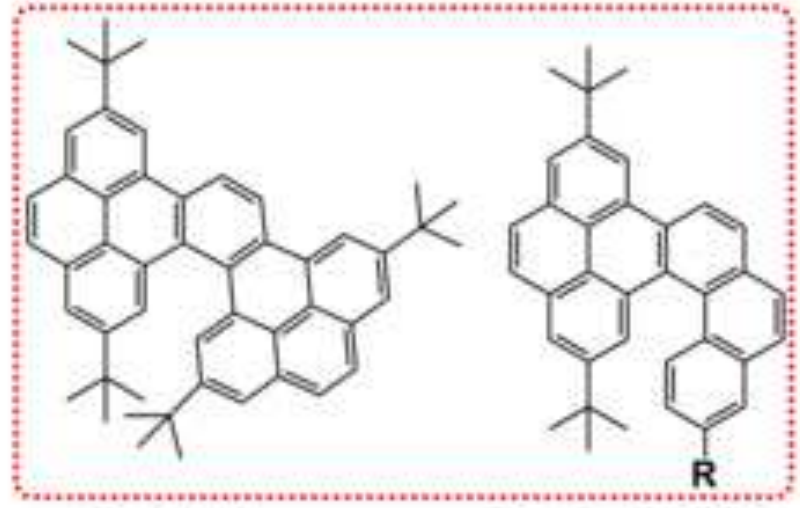

$7 a(58 \%)$
$7 b: R=H(58 \%)$

$7 c: R=O M e(65 \%)$

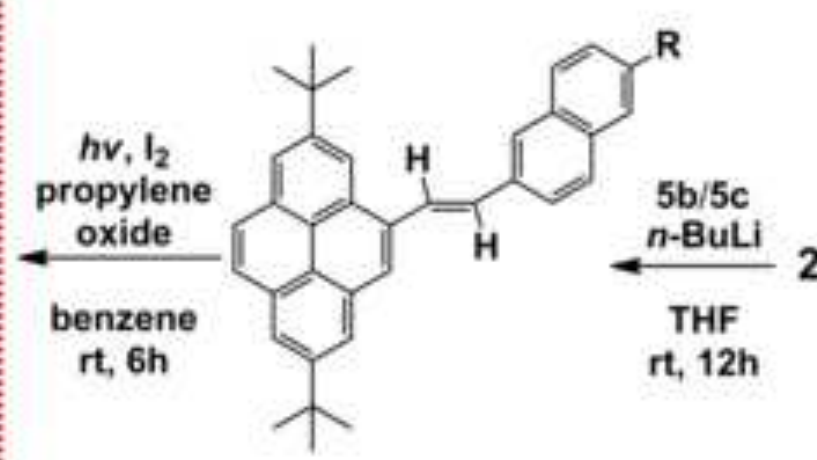

(E) $-6 \mathrm{~b}: \mathbf{R}=\mathbf{H}(73 \%)$ $6 c: R=$ OMe $(70 \%)$ 

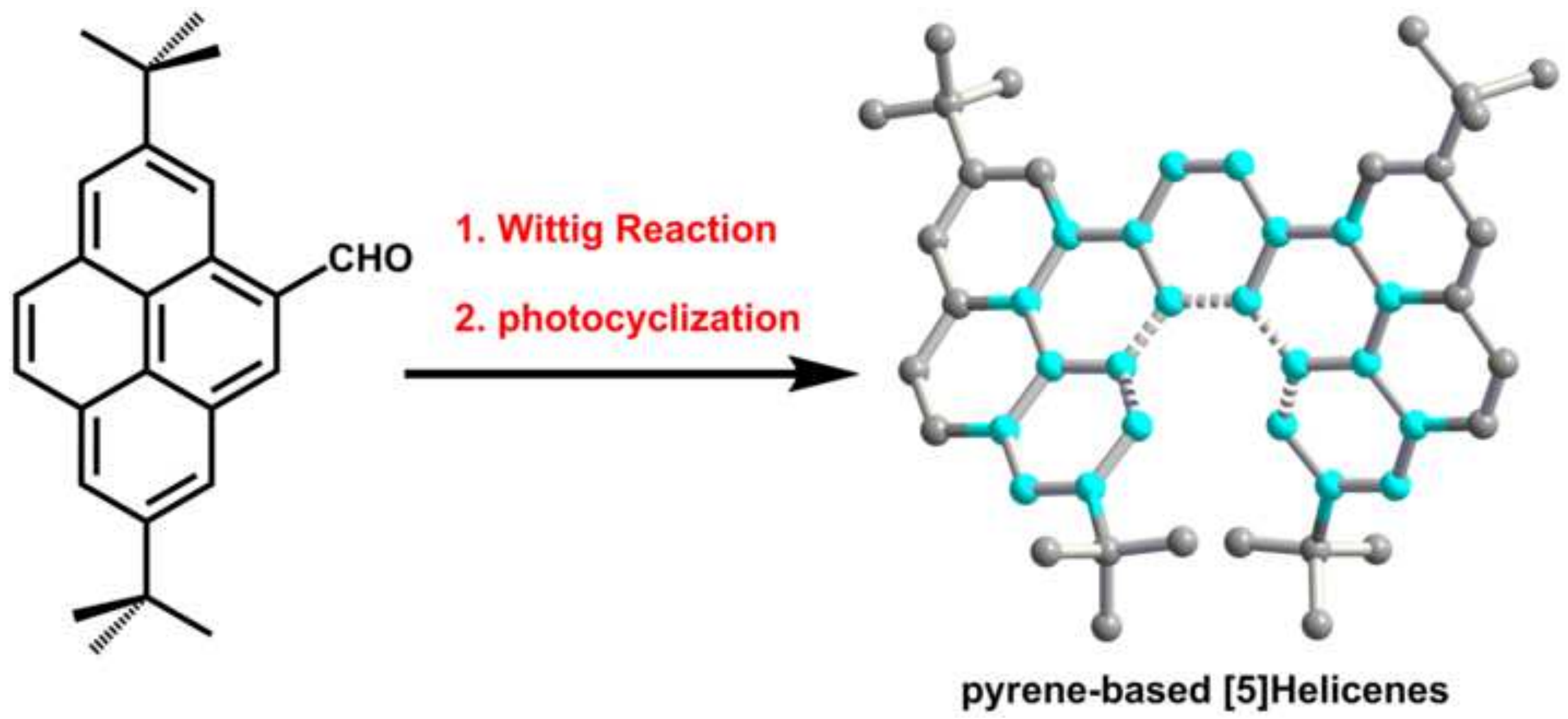


\section{Click here to access/download Additional Material - Author \\ checkcif.pdf}


CIF

[checkCIF Results]

\section{Click here to access/download
CIF \\ Click here to access/download
CIF
submit cif.cif \\ Click here to access/download
CIF
submit cif.cif

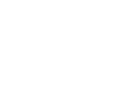 \\ Click here to access/download
CIF}

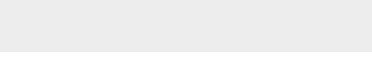

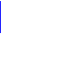

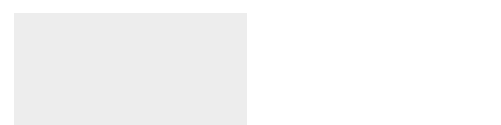

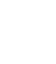

